\title{
SEJARAH PENDIDIKAN SEKOLAH KRISTEN GEREJA TORAJA SUATU KAJIAN HISTORIS KRITIS TENTANG PERAN GEREJA TORAJA MELAKSANAKAN PENDIDIKAN SEKOLAH KRISTEN DARI MASA ZENDING SAMPAI ERA REFORMASI
}

\author{
Yan Malino $^{1}$ \\ Daniel Ronda ${ }^{2}$
}

\begin{abstract}
ABSTRAK
Alkitab menyaksikan bahwa mendidik merupakan aktivitas yang tak terpisahkan dari pelayanan Tuhan Yesus dan Dia tampil sebagai guru di panggung sejarah. Pendidikan merupakan bagian integral dari perintah agung Tuhan Yesus. Gereja yang sungguh mengasihi Tuhan Yesus dan yang tetap setia melaksanakan amanat agung adalah gereja yang tidak mengabaikan pendidikan dan tetap melaksanakannya secara konsisten. Gereja di segala abad bertanggung jawab untuk mencerdaskan umat manusia melalui pendidikan.

Sejarah membuktikan bahwa sekolah-sekolah yang dikelolah oleh gereja berawal dari masa zending sampai dengan masa Gereja Toraja telah mewujudkan restoration of the world yang merupakan tugas panggilan gereja terhadap dunia. Sekolah-sekolah Kristen, para pelajar Kristen, dan guru-guru Kristen serta seluruh komponen pendidikan sekolah kristen telah membuktikan diri sebagai agent change bagi kemajuan Toraja. Kader-kader gereja dan masyarakat yang ditelorkan menjadi motivator dan fasilitator pembangunan bagi kemajuan gereja dan masyarakat Toraja pada khususnya, bangsa dan negara pada umumnya. Ada pun faktor-faktor berpengaruh yang mengiringi perkembangan sekolah-sekolah Kristen Gereja Toraja dalam sepanjang sejarahnya, yaitu: daya, dana, dan sarana prasarana penunjang proses pendidikan.
\end{abstract}

Kata Kunci: Pendidikan Sekolah Kristen, Zending, Gereja Toraja

\footnotetext{
${ }^{1}$ Alumni Pascasarjana STT Jaffray 2013 dengan gelar M.Pd.K.

${ }^{2}$ Dosen Pascasarjana STT Jaffray dan Ketua STT Jaffray 


\section{PENDAHULUAN}

\section{Latar Belakang Masalah}

Tahun 2013 merupakan tahun peringatan bagi seluruh masyarakat Toraja, baik yang ada di daerah Toraja maupun di luar Toraja. Dikatakan sebagai tahun peringatan, sebab sudah seabad Injil Masuk Toraja (IMT). Segenap masyarakat dan orang Toraja bersyukur kepada Tuhan karena sudah 100 tahun Tuhan memberkati Toraja, masyarakat dan orang Toraja melalui pemberitaan Injil oleh orang-orang yang diutus Tuhan dari luar daerah Toraja pada tahun 1913.

Tahun 2013 menjadi momentum peringatan bersejarah untuk merenungkan, mensyukuri dan merayakan perbuatan-perbuatan besar Allah kepada Toraja, masyarakat dan orang Toraja dalam kurun waktu 100 tahun. Kebenaran keyakinan Rasul Paulus menjadi nyata bahwa; "...Injil adalah kekuatan Allah yang menyelamatkan orang yang percaya..." (Roma 1:16). Tak boleh dipungkiri bahwa Injil telah menyelamatkan Toraja dan orang Toraja. Injil telah membawa perubahan-perubahan mendasar dan besar dalam berbagai bidang kehidupan yang telah dinikmati masyarakat dan orang Toraja.

Secara khusus kemajuan di bidang pendidikan formal dapat dinikmati oleh orang Toraja karena masuknya Injil. Pendidikan melalui sekolah menjadi pilar penopang penyebaran Injil di Toraja. Pendidikan yang dikembangkan oleh para zending dengan mendirikan sekolah di berbagai wilayah Toraja telah mengubahkan manusia Toraja.

Mendidik merupakan aktivitas yang tak terpisahkan dari pelayanan Tuhan Yesus. Kitab Injil sangat jelas menampilkan bahwa Tuhan Yesus adalah pemerhati sekaligus pelaku yang sangat serius menangani pendidikan. Puncak keseriusan Tuhan Yesus dalam bidang pendidikan tercantum dalam amanat agung-Nya (Matius 28: 19-20). Jadi pendidikan merupakan bagian integral dari perintah agung Tuhan Yesus.

Memerhatikan teladan dan amanat agung Tuhan Yesus, maka sesungguhnya pendidikan merupakan bagian integral dari pelayanan gereja. Gereja yang sungguh mengasihi Tuhan Yesus dan yang tetap setia melaksanakan amanat agung adalah gereja yang tidak mengabaikan pendidikan dan tetap melaksanakannya secara konsisten. Gereja di segala abad bertanggung jawab untuk mencerdaskan umat manusia melalui pendidikan.

Bidang pendidikan merupakan bagian dari misi gereja dalam upaya lebih memanusiakan manusia. Keterlibatan gereja-gereja di Indonesia melaksanakan pendidikan formal melalui pendirian sekolah-sekolah Kristen merupakan wujud dari keikutsertaan gereja di bidang pendidikan formal dalam upaya mencerdaskan bangsa. Keterlibatan 
gereja-gereja dalam melaksanakan pendidikan melalui sekolah-sekolah Kristen telah memberi kontribusi positif dalam upaya mencerdaskan anak-anak ibu pertiwi. Sudah banyak lulusan dari lembaga pendidikan Kristen yang telah mengharumkan nama bangsa Indonesia di pentas dunia melalui prestasi yang diukir dalam berbagai bidang kehidupan.

Dalam rangka mewujudkan misinya di bidang pendidikan, maka Gereja Toraja (GT) pun mendirikan sekolah-sekolah Kristen mulai dari Pendidikan Anak Usia Dini (PAUD) sampai Perguruan Tinggi (PT). Patut disyukuri bahwa Tuhan sudah memberkati bangsa Indonesia pada umumnya dan Toraja pada khususnya melalui institusi pendidikan GT.

Dalam era kompetitif di mana mutu menjadi andalan, maka masyarakat tidak akan terlalu mempersoalkan lembaga mana yang menjadi penyelenggara pendidikan. Pandangan semacam ini memberi peluang bagi lembaga pendidikan Kristen dalam persaingan melaksanakan pendidikan yang berkualitas. Gereja seharusnya berupaya menjadi pilar dalam pengembangan pendidikan yang berkualitas.

Dalam waktu yang cukup lama sekolah-sekolah Gereja Toraja menjadi sekolah yang baik, bermutu dan menghasilkan alumni yang berkualitas pada zamannya. Sumber Daya Manusia (SDM) Toraja membahana secara nasional sebagai SDM berkualitas di Indonesia Timur. Hal itu ditandai dengan hadirnya putra-putri Toraja yang memegang peranan dalam berbagai instansi pemerintah maupun swasta dan di berbagai perusahaan terkemuka di berbagai pelosok nusantara.

Namun sekolah-sekolah Kristen milik Gereja Toraja (GT) pun tak luput menuai kritik tajam dari berbagai pihak. Ada indikator; walaupun belum dapat dijadikan indikator mutlak bahwa mutu pendidikan di Toraja sedang mengalami keadaan yang memprihatinkan. Produktivitas dan prestasi akademik lembaga pendidikan Kristen menurun, daya saing tamatan sekolah-sekolah di Toraja melemah, dan etos kerja pun melemah. Majelis Pertimbangan Gereja Toraja (MPGT) dalam laporan pertanggungjawabannya pada sidang SMS XXIII GT di Tallunglipu tanggal 2-9 Juli 2012 menilai bahwa mutu pendidikan menyangkut aspek Emotional Quotion (EQ) maupun Spiritual Quotion (SQ) di sekolah-sekolah milik GT terkesan kurang mendapat perhatian serius. ${ }^{3}$ Model dan metode Pendidikan Agama Kristen hanya sekadar pengajaran agama Kristen; belum benar-benar menjadi kesempatan untuk mendidik nara didik tentang kasih kepada Allah dan kepada manusia.

MPGT juga mencatat bahwa peran serta warga gereja/jemaat GT dalam upaya memajukan pendidikan sangat minim. ${ }^{4}$ Pertanyaannya

\footnotetext{
${ }^{3}$ Dokumen, Laporan Majelis Pertimbangan Gereja Toraja pada SSA XXIII Gereja Toraja di Tallung Lipu, 2-9 Juli 2012.

${ }^{4}$ Ibid.
} 
adalah apa faktor penyebab rendahnya animo warga gereja mendukung upaya pengembangan pendidikan di sekolah-sekolah yang bernaung di bawa Yayasan Pendidikan Kristen milik GT? Apakah sense of belonging warga GT terhadap sekolah-sekolah rendah? Jawaban terhadap pertanyaan ini tentu membutuhkan penelitian khusus; salah satunya adalah melalui penelusuran sejarah keterlibatan GT mendirikan sekolahsekolah Kristen.

Berdasarkan uraian di atas, maka sejarah peran Gereja Toraja melaksanakan pendidikan sekolah Kristen memiliki arti penting bagi perkembangan pendidikan sekolah Kristen Gereja Toraja masa kini dan masa akan datang. Artinya segala bentuk kritik terhadap berbagai kekurangan pendidikan sekolah Kristen yang dikelola Gereja Toraja sekarang ini, tidak menutup kemungkinan penyebabnya adalah karena kurang tangggap mengambil hikma dari pengalaman sejarahnya. Tidak menutup kemungkinan juga permasalahan yang di hadapi sekarang ini, jalan penyelesaiannya dengan belajar pada masa lampau. Namun sampai genap 100 Tahun Injil Masuk Toraja yang adalah juga 100 tahun Pendidikan Sekolah Kristen di Toraja (PSKT); kajian sejarah tentang pendidikan sekolah Kristen Gereja Toraja secara ilmiah masih sangat minim.

Memerhatikan peran strategis Gereja Toraja dalam mencerdaskan kehidupan bangsa dan sumbangsih yang telah dinyatakan dalam sistem pendidikan nasional Indonesia, kemudian menyikapi tantangan serta persoalan yang dihadapi oleh lembaga pendidikan Kristen, serta secara khusus dalam rangka memaknai penghayatan mensyukuri 100 tahun Injil masuk Toraja; maka penulis selaku orang Toraja tertarik untuk mengkaji secara historis kritis Peran Gereja Toraja Melaksanakan Pendidikan Sekolah Kristen dari Masa Zending sampai Era Reformasi. Sebab salah satu panggilan hidup orang Kristen menurut kesaksian Alkitab adalah menceritakan perbuatan-perbuatan Allah yang besar (Latin: Magnalia Dei). ${ }^{5}$

"Semarak kemuliaan-Mu yang agung dan perbuatan-perbuatanMu yang ajaib akan kunyanyikan. Kekuatan perbuatan-perbuatan$\mathrm{Mu}$ yang dahsyat akan diumumkan mereka, dan kebesaran-Mu hendak kuceritakan. Peringatan kepada besarnya kebajikan-Mu akan dimasyhurkan mereka, dan tentang keadilan-Mu mereka akan bersorak-sorai" (Maz. 145:5-7).

Pada satu sisi, menulis sejarah adalah bagian dari pengakuan iman untuk menceritakan perbuatan-perbuatan Allah yang besar. Meneliti

\footnotetext{
${ }^{5}$ Panitia 100 Tahun Injil Masuk Toraja, Panduan Umum Ibadah Syukur dan Perayaan 100 Tahun Injil Masuk Toraja (Rantepao: Sekretariat Panitia, 2013), 3.
} 
dan menulis sejarah pendidikan sekolah Kristen di Toraja merupakan refleksi nyata atas kasih Allah yang mengubahkan Toraja dan orang Toraja melalui pendidikan sekolah. Pada sisi yang lain, sejarah menuntun untuk melakukan instrospeksi dan evaluasi. Sebab melalui sejarah dapat diketahui dan diakui berbagai kelemahan dan kekurangan yang ada, sehingga lebih bijaksana dan berhikmat dalam melakukan pelayanan selanjutnya. "Ajarlah kami menghitung hari-hari kami sedemikian, hingga kami beroleh hati yang bijaksana" (Mazmur 90:12). Artinya sejarah tidak dapat diabaikan dalam memproyeksi masa depan, memprediksi peluang dan tantangan. Paling tidak, demikianlah pentingnya sejarah untuk diteliti dan dicatatkan.

\section{Pengertian Pendidikan Sekolah Kristen}

Kata Inggris yang diterjemahkan dengan kata pendidikan adalah "education". Education berasal dari kata Latin, "ducere" yang artinya membimbing (to lead). Ducere mendapat awalan "e" yang artinya keluar (out). ${ }^{6}$ Educere berarti membimbing keluar. Kata Yunani yang memiliki makna yang sama dengan pendidikan adalah "paedagogike" yang merupakan gabungan dari kata "paes" artinya anak, dan "ago" artinya aku membimbing. ${ }^{7}$ Paedagogik berarti aku membimbing anak. Jadi secara etimologis inti kata pendidikan adalah tindakan membimbing.

Robert W. Pazimo dalam bukunya Foundantional Issues in Christian Education, merumuskan tentang pendidikan Kristen sebagai mana dikutip Sidjabat sebagai berikut:

Pendidikan Kristen merupakan upaya ilahi dan manusiawi yang dilakukan secara bersahaja dan berkesinambungan, untuk memberikan pengetahuan, nilai-nilai, sikap-sikap, keterampilan, sensitivitas, tingka laku yang konsisten dengan iman Kristen. Pendidikan mengupayakan perubahan, pembaruan, dan reformasi pribadi-pribadi, kelompok, dan struktur oleh kuasa Roh Kudus, sehingga bersesuaian dengan kehendak Allah, sebagaimana dinyatakan dalam kitab suci, terutama dalam Kristus Yesus, serta diwujudkan oleh upaya itu. ${ }^{8}$

${ }^{6}$ Daniel Nuhamara, Materi Pokok Pembimbing Pendidikan Agama Kristen; Modul 1-9 (Jakarta: Dirjen Bimas Kristen Protestan-Departemen Agama Republik Indonesia, 1995), 2. 1991), 69

${ }^{7}$ Abu Ahmadi dan Nur Uhbiyati, Ilmu Pendidikan (Jakarta: PT Rineka Cipta,

${ }^{8}$ B. Samuel Sidjabat, Strategi Pendidikan Kristen: Suatu Tinjauan Teologis-Filosofis (Yogyakarta: ANDI Offset, 1999), 106. 


\section{SEJARAH PERAN GEREJA TORAJA MELAKSANAKAN PENDIDIKAN SEKOLAH KRISTEN}

\section{Pekabaran Injil di Toraja dan Berdirinya Gereja Toraja}

Belanda tiba di daerah Toraja pada tahun 1905 dan berhasil menaklukkannya secara tuntas pada tahun 1906. Kekristenan mulai diperkenalkan di Toraja, tidak lama setelah pemerintah kolonial menumpas perlawanan rakyat Toraja yang dipimpin oleh Pong Tiku. Pada tahun 1908 pemerintah kolonial Belanda membuka Landschapschool (sekolah swapraja) di Makale dan Rantepao yang dipimpin oleh guruguru Kristen. Sekalipun sekolah pemerintah ini berstatus "netral", namun guru-guru di Landschap mengajarkan agama Kristen kepada para murid Landschap. ${ }^{9}$ Maksud pemerintah kolonial membuka sekolah adalah selain untuk mendapatkan tenaga administrasi kolonial, juga sebagai upaya untuk mengkristenkan penduduk di daerah-daerah pegunungan Sulawesi.

Mulai tahun 1912, kegiatan guru-guru Kristen untuk memberitakan Injil Yesus Kristus di sekolah didukung oleh pendeta Gereja Protestan (Indische Kerk) di Makassar, yaitu R.W.F Kijtenbelt, yang didampingi oleh pendeta bantu; Jonathan Kelling. Atas pimpinan Roh Kudus, S. Sipasulta seorang guru asal Ambon sebagai kepala sekolah Lanschap di Makale dapat membawa 20 muridnya pada penerimaan Yesus Kristus sebagai juru selamatnya yang di baptis pada tanggal 16 Maret 1913. ${ }^{10}$ Pembaptisan murid sekolah Landschap itulah yang diterima sebagai buah bungaran hasil PI dalam Gereja Toraja, walau tentang jumlah orang yang dibaptis ada beberapa pendapat berbeda.

Pada tahun 1915 pelayanan Indische Kerk di Makale diambil alih oleh Gereformeerde Zendingsbond (GZB). GZB adalah lembaga PI Belanda yang didirikan pada tanggal 6 Pebruari 1901 di Ultrecht oleh orang-orang Gereformeerde yang masih tetap tinggal dalam Hervormde Kerk (De Gereformeerde Bond inde Hevormde Kerk) yang merupakan gereja negara waktu itu. Tujuan berdirinya adalah mengutus para zendeling untuk memberitakan Firman Allah kepada bangsa-bangsa yang belum mengenal Yesus Kristus, khususnya bangsa jajahan Belanda. Tujuannya didasarkan pada Yohanes 10:16.

\footnotetext{
${ }^{9}$ Theodorus Kobong, Injil dan Tongkonan: Inkarnasi, Kontekstualisasi, Transformasi (Jakarta: BPK Gunung Mulia, 2008), 125.

${ }^{10}$ Surat Konsul Zending C. W. Th. Van Boetzelaar Kepada Direktor Zending J.W. Gunning Weltevreden, 21 Nopember 1913. ArvdZ, 8-3; dalam Th. Van den End: Sumber-Sumber Zending Tentang Gereja Toraja 1901-1961, dokumen 8 (22) , (Jakarta: BPK Gunung Mulia, 1994), 62-63. .
} 
GZB merupakan badan pekabar Injil yang mendapat izin resmi pemerintah untuk melakukan penginjilan di Toraja, Luwu, dan Enrekang. Sang pionir yang pertama kali diutus oleh GZB sebagai pekabar Injil sejak dari berdiri adalah A.A. van de Loosdrecht. Ia berangkat dari negeri Belanda pada tanggal 5 September 1913. Setelah mendapatkan keterangan tentang Toraja dari konsulat zending dan dari Dr. N. Adriani di Jakarta, ia melanjutkan perjalanan ke Makassar. Di Makassar ia bertemu seorang guru yang bernama Manembu yang bersedia menemaninya ke Toraja. Dari Makassar, A.A. van de Loosdrecht melanjutkan perjalanan ke Palopo dan dari Palopo menuju Toraja yang ditempuh dengan berjalan kaki $\pm 60 \mathrm{~km}$. Mereka tiba di Rantepao pada tanggal 10 Nopember 1913.

Dalam memulai pekerjaannya, A. A. van de Loosdrecht pertamatama melakukan perundingan dengan pemuka-pemuka masyarakat untuk mendirikan sekolah-sekolah zending. Tawaran tersebut disambut baik dan positif oleh para kepala-kepala distrik setempat. Ia mencurahkan perhatian pikiran dan tenaganya secara serius di bidang pendidikan dengan membuka sekolah diberbagai distrik di Toraja. Di samping sebagai zendeling leraar (utusan PI) yang setia berkeliling memberitakan Injil Yesus Kristus di Toraja dan sekitarnya (Rongkong, Pantilang dan Ranteballa di Luwu'); A. A. van de Loosdrecht juga berperan sebagai schoolbeherder (pengawas sekolah). ${ }^{\text {ll }}$ Dalam menjalankan tugasnya, ia mendapat sokongan dari istri yang setia mendampinginya dalam pelayanan.

Masa PI dari GZB berlangsung dari tahun 1913 sampai terbentuknya Institusi Gereja Toraja pada tahun 1947. J.A. Sarira membagi masa zending GZB menjadi tiga dekade, yaitu : masa penaburan Injil (1913-1925), masa penanaman secara teratur (1926-1941), dan masa ujian (1942-1946); dan masa Gereja Toraja dibagi menjadi tiga dekade sampai tahun 1965, yaitu : masa peralihan (1947-1950), masa berdiri sendiri/masa ujian II (1950-1965), dan masa persiapan untuk pembangunan dan pembaharuan. ${ }^{12}$

Sebenarnya pada akhir tahun 1930-an, GZB merencanakan untuk membentuk gereja di daerah pelayanannya. Namun tertunda karena pendudukan Jepang (1942-1945) dan baru terwujud sesudah pendudukan Jepang. Pada tanggal 25-28 Maret 1947, berkumpul di Rantepao 35 jemaat dari 18 klasis hasil PI GZB untuk membahas realisasi

${ }^{11}$ J. R. Pasolon, Garis Besar Sejarah Gereja Toraja (Bagian I, 1913-1967) dalam Sejarah Gereja Toraja 1913-2013 (Draff), (Rantepao : Institut Gereja Toraja, 2013), 12.

${ }^{12}$ J. A. Sarira, Seri Benih Yang Tumbuh, Jilid VI, Suatu Studi Mengenai gereja Toraja (Jakarta: LPS-DGI, 1975), 61. 
rencana GZB untuk membentuk sebuah gereja di daerah Toraja. Dalam persidangan tersebut GZB mendewasakan jemaat-jemaat yang sudah ada dengan nama Gereja Toraja. Sistem pemerintahan gerejawi yang disepakati adalah sistem presbiterial-sinodal. Dalam pertemuan tersebut dipilih tiga pejabat gerejawi sebagai pemimpin Gereja Toraja yang baru berdiri, yaitu Ds. D.J. van Dijk sebagai ketua dan Ds. P.S. Palisungan sebagai sekertaris yang berfungsi sebagai moderamen. Kendatipun Gereja Toraja sudah berdiri, namun secara praktis pekerjaan dan kebijakan gereja masih dibawa kendali GZB sampai terbentuknya kepemimpinan secara defenitif di tangan para pendeta Toraja pada awal tahuan 1950-an. Kebutuhan finansial masih sepenuhnya ditanggung GZB.

Gereja Toraja berdiri dalam suasana di mana Indonesia baru saja memproklamasikan kemerdekaannya dan masih mengalami masa revolusi (perang kemerdekaan). Pembentukan Gereja Toraja tidak dapat dilepaskan dari pengaruh kenyataan bahwa secara de facto Indonesia sebagai wilayah jajahan Belanda sudah berdaulat sebagai bangsa yang merdeka pada tahun 1945.

\section{Konstruksi Historis}

Setelah meneliti berbagai dokumen, seperti buku, laporan, keputusan-keputusan dan catatan-catatan yang memuat data tentang peran Gereja Toraja melaksanakan pendidikan Sekolah Kristen dari zaman zending sampai sekarang, maka penulis membagi bangun historisnya menjadi tiga periode, yaitu Masa zending (1913-1942), Masa Pendudukan Jepang, dan MasaGereja Toraja (1947-2013).

\section{Masa Zending (1913-1942)}

Tentara pasukan perang Belanda yang berangkat dengan berjalan kaki dari daerah Luwu melalui tondok Balusu tiba di Rantepao pada Maret 1906. Tentara Belanda mendapatkan perlawanan dari penguasa lokal Toraja seperti Pong Tiku dan Pong Maramba'. Namun pada akhir tahun 1906 tentara Belanda menguasai Toraja.

Pada tahun 1921 Sekolah Lanschapscool di Rantepao menjadi Sekolah gubernemen yang pada tahun 1922 berubah menjadi Vervolgschool, yaitu kelas 4 dan 5 dan kelas $1-3$ dijadikan sekolah desa yang diserahkan kepada Zending. Vervolgschool itulah yang sekarang dikenal sebagai SDN 2 Rantepao dan sekolah desa tersebut, sekarang dikenal sebagai SD Kristen Rantepao V. Sebab waktu itu terjadi kompromi antara pemerintah kolonial dengan zending, yaitu tiga tahun pertama ditangani zending dan dua tahun berikutnya ditangani pemerintah kolonial dengan ketentuan zending diwajibkan mendirikan Asrama. Asrama yang 
dimaksud terwujud di Makale pada tahun 1924 dan di Rantepao pada tahun 1926. Selanjutnya penulis akan menguraikan secara deskriptifnaratif sekolah-sekolah Kristen yang didirikan oleh zending yang ada di wilayah Makale dan wilayah Rantepao menurut masanya.

\section{Pendidikan Sekolah Kristen Umum di Wilayah Makale}

Atas kehendak Tuhan melalui sekolah Lanschap di Makale, maka S. Sipasulta sebagai kepala Sekolah tersebut, dapat menuntun 20 orang murid pada pengenalan akan Injil Kristus bahwa Yesus Kristus adalah Tuhan dan juruselamat dunia. Pada tanggal 16 Maret 1913 oleh pimpinan Roh Kudus, 20 orang murid tersebut dibaptis oleh F. Kelleng seorang hulpprediker dari Bontain. Baptisan atas 20 orang murid Lanschap di Makale merupakan buah bungaran PI di Toraja dan sekaligus cikal bakal lahirnya GT di kemudian hari. Momentum pembabtisan pertama tersebutlah yang diperingati oleh GT sebagai awal masuknya Injil Yesus Kristus di Toraja.

Pemberitaan Injil dan pembukaan sekolah di daerah Makale (sekarang ibu kota kabupaten Tana Toraja) dilakukan oleh Indische Protestanche Kerk (sering disingkat Indiche Kerk). Kala itu sebelum zending dari GZB datang, penginjilan dan pendidikan Kristen di daerah Sulawesi Selatan dipelopori oleh Indiche Kerk. Di tahun 1913 Indiche Kerk telah membuka 4 sekolah, yaitu di Rembon, Batualu, Buakayu, Gandang Batu, dan Rano. ${ }^{13}$ Pada tahun 1914 dibuka 5 sekolah, yaitu: Leatung, Randanan, Mebali, Gandang batu dan Rano. Guru-guru yang pertama kali bekerja pada 9 sekolah yang didirikan oleh Indiche Kerk, yaitu: Peluppessy, Tanamal, Supit, Tawaluyan, Gerung, S. Piring, Siehainenia, Soemolang, dan H. Kountoer. ${ }^{14}$

Pada bulan April 1915, sembilan sekolah tersebut di atas diserahkan pengelolaannya oleh Indiche Kerk kepada GZB. Untuk menangani wilayah pelayanan di Makale, A. A. van de Loosdrecht mengusulkan kepada GZB agar diutus seorang tenaga zending karena wilayah pelayanannya di Rantepao sudah terlalu luas. Usulan tersebut dipenuhi oleh GZB dengan mengutus D. C. Prins dari Utrechtsche Zendings yang bekerja di Halmahera atas panggilan dari GZB. ${ }^{15}$ Beliau tiba dari Halmahera pada bulan Oktober 1915 dan menetap di Burake. D.C Prins menjadi evangelis dan Schoolbeheerder untuk wilayah Makale.

\footnotetext{
${ }^{13}$ J. A. Sarira, Sketsa Pendidikan Kristen Gereja Toraja (Toraja: Panitia Panca Dasa Warsa Pendidikan Kristen gereja Toraja, 1967), 17.

${ }^{14}$ J. A. Sarira, Benih Yang Tumbuh, Jilid VI (Rantepao: Badan Pekerja Sinode Gereja Toraja, 1974), 24.

${ }^{15}$ Sarira, Benih Yang Tumbuh, Jilid VI, 24.
} 
D. C. Prins digantikan oleh P. Zijlstra pada bulan Januari 1920 dan menetap di Kondoran. P. Zijlstra bekerja sebagai evangelis dan Schoolbeheerder sampai tahun 1928 yang melayani di resort Sanggala'Makale. Selama pelayanannya, beliau membuka sekolah di Uluwai, Kasimpo, Boto', Palesan, Tapparan dan Tokesan. ${ }^{16}$ P. Zijlstra digantikan oleh H. Pol yang melayani dari tahun 1928-1934. Selanjutnya dari tahun 1934-1937, yang bertindak sebagai Schoolbeheerder di Makale adalah A. Belksma.

Selain sekolah-sekolah yang telah diuraikan di atas, juga didirikan beberapa sekolah, yaitu: Vervgelgschool di Makale, Volkschool A dan Volkschool B di Makale, Volkschool di Malimbong, Mendetek, Tampo, Miallo dan Balepe'. Juga didirikan Schakelschool di Makale oleh J. Tanis pada tanggal 30 Juni 1926. Sebelum Schakelschool, sebenarnya yang direncanakan GZB untuk didirikan adalah HIS yang telah disetujui oleh gubernur Sulawesi, yaitu: tn. Vorstman. Tapi gubernur yang baru, yaitu Couvreur memberi nasihat supaya mendirikan Schakelschool karena dinilai akan lebih bermanfaat untuk Toraja. ${ }^{18}$ Dalam operasionalnya Schakelschool ini bersubsidi penuh dari pemerintah. Guru-guru yang tercatat pernah mengajar pada Schakelschool Makale, yaitu: Staathof, Nanlohy, Wiriopawiro, Elifas, Seifattiratu, Pardede, Adriaandsz, Sampe Pandin, Nn. Mailangkay, Rompas, dan Dotulong.

Pada tahun 1938, tepatnya pada perayaan 25 tahun Injil masuk Toraja, sekolah Kristen di Makale berjumlah 27 buah sekolah dengan 3178 murid. ${ }^{19}$ Termasuk tiga buah sekolah di daerah Duri-Enrekang, yaitu: sekolah di Redak, Baroko, Curio yang diserahkan oleh Indiche Kerk kepada GZB pada tahun 1926. Selain membuka sekolah, strategi PI lain yang diterapkan oleh Indiche Kerk ialah mendekati para bangsawan/pemimpin lokal. Hasinya pada tahun 1913 telah membaptis Puang Rante Allo (Puang Makale) dan Yohanes Lambe' dari Awa'.

\section{Pendidikan Sekolah Kristen Umum di Wilayah Rantepao}

Pada tanggal 5 September 1913 A.A. van de Loosdrecht bersama istrinya yaitu Alida yang baru dinikahinya, berangkat dari Belanda menuju ke Indonesia. Dia tiba di Jakarta dan mendapat gambaran tentang Toraja dari konsulaat zending dan Dr. N. Adriani. Berbekal pengetahuan tersebut, ia melanjutkan perjalanan ke Makassar. Di

${ }^{16}$ J. A. Sarira, Sketsa Pendidikan Kristen Gereja Toraja (Toraja: Panitia Panca Dasa

Warsa Pendidikan Kristen gereja Toraja, 1967), 17.

${ }^{17}$ Sarira, Sketsa Pendidikan Kristen Gereja Toraja, 17.

${ }^{18}$ Ibid., 18.

${ }^{19} \mathrm{Ibid}$. 
Makassar beliau mendapatkan seorang guru yang bernama Manembu yang bersedia menemaninya ke Toraja. Dari Makassar, A. A. van de Loosdrecht bersama Manemboe menuju ke Palopo dan dari Palopo selanjutnya berjalan kaki ke Toraja. Mereka tiba di Rantepao pada tanggal 10 Nopember 1913.

A. A. van de Loosdrecht dalam memulai pekerjaannya segera berunding dengan para kepala distrik dan tokoh masyarakat setempat untuk mendirikan sekolah. Rencana A. A. van de Loosdrecht untuk mendirikan sekolah mendapat sambutanyang baik oleh kepala-kepala distrik dan tokoh-tokoh masyarakat. Hal tersebut ditandai oleh banyaknya permintaan dari para kepala distrik untuk mendirikan sekolah di wilayah kekuasaannya. Pong Maramba', kepala distrik Kesu'Tikala meminta sekurang-kurangnya 6 sekolah di daerahnya. Pada saat itu juga di bulan Nopember 1913 guru Manemboe ditugaskan membuka sekolah zending yang pertama di Toraja, yaitu di Tonga distrik Kesu'.

Menyambut peluang yang ada dan menyadari tantangan yang menghadang, maka pada Desember 1913 A. A. van de Losdrect bersama dengan 3 orang pemuda Toraja, yaitu Bokko', Kadang, Taroe' berangkat ke Poso untuk belajar bahasa Toraja dan menyusun buku bacaan dalam bahasa Toraja. Mereka dibimbing oleh Dr. N.A. Adriani, seorang utusan Nederlandsch Bijbelgenootschap yang sudah lama menyelidiki bahasa-bahasa Toraja di Poso.

Tanggal 9 Mei 1914 mereka kembali ke Rantepao dengan membawa 2 orang guru, yaitu: Runtuwene dan Abraham, dan membawa pula 2 orang murid, yaitu: Konda dan Barina. Hasil dari perjalanan berguru ke Poso adalah terbitnya buku pelajaran membaca (bahasa) yang berjudul "Soera' Iate Peladaran Basa Soera"' pada tahun yang sama dan yang dicetak ulang pada tahun 1917. Ketiga pemuda Toraja yang kembali dari Poso ditambah seorang pemuda lainnya, yaitu Palobo', menjadi murid katekisasi pertama yang dibaptis pada tanggal 23 Mei 1915 dan menjadi anggota jemaat pertama di Rantepao.

Jadi jumlah sekolah yang dibuka oleh A. A. van de Losdrect di onderafdeling Rantepao pada tahun 1914 adalah 11 dengan jumlah murid sekitar 851 - 927 orang. ${ }^{20}$ Dalam menangani sekolah-sekolah yang didirikan, beliau dibantu oleh guru-guru yang kebanyakan berasal dari Manado, yaitu: 1) Loing yang membantu untuk sekolah di Nanggala, 2) B. R. Manemboe yang membantu untuk sekolah di Sa'dan, 3) S. Akay yang membantu untuk sekolah di Tondoklitak, 4) Manoempil yang membantu untuk sekolah di Panggala', 5) Manapode yang membantu untuk sekolah di Baruppu', 6) Runtuwene yang membantu untuk

${ }^{20}$ J. A. Sarira, Sketsa Pendidikan Kristen Gereja Toraja (Toraja: Panitia Panca Dasa Warsa Pendidikan Kristen gereja Toraja, 1967), 10. 
sekolah di Pali-Bittuang, 7) Eli Kasenda yang membantu untuk sekolah di Bori' dan kemudian untuk sekolah di Raanteballa, 8) A.G. Lapian yang membantu untuk sekolah di Tondon, 9) Titus yang membantu untuk sekolah di Penanda.

Namun setelah sekolah-sekolah tersebut berdiri dan beroperasi, bukanlah tanpa hambatan. Jumlah murid dari ll sekolah sebagaimana tersebut di atas, menurun menjadi 509 murid. Penyebab utamanya adalah dari diri murid sendiri dan orang tuanya. Murid-murid kurang bisa menyesuaikan diri dengan tata tertib sekolah. Sebab umumnya mereka sudah terbiasa hidup bebas di padang luas menggembalakan kerbau. Kondisi itu didukung oleh para orang tua murid yang tidak mau jika anaknya ke sekolah karena tenaga anak-anak mereka diperlukan untuk menggembalakan kerbau, untuk bekerja di sawah dan di ladang. Tingkat ketidakhadiran murid di sekolah terlalu tinggi terutama pada musim panen padi dan kopi. Para orang tua juga takut anaknya akan dijadikan tentara Belanda setelah keluar dari sekolah.

Kendatipun para kepala desa, kepala distrik beserta aparatnya telah menggunakan tindak kekerasan kepada para murid yang lari dari sekolah atau tidak masuk sekolah; termasuk bertindak tegas kepada orang tuanya. Guru-guru menjemput ke rumahnya, di sawah, di ladang dan di tempat-tempat persembunyian lainnya. Namun tetap saja tidak membuat jerah para murid yang sering kali tidak hadir atau lari dari sekolah dan menyadarkan orang tua akan pentingnya pendidikan sekolah bagi anaknya. Justru ketika mereka ditemukan oleh gurunya, si murid terus menangis dan dalam keadan itu orang tuanya mulai membela sang anak. Tidak tanggung-tanggung orang tua justru dengan sengaja menyembunyikan keberadaan anaknya.

Kesulitan lain yang dihadapi adalah tenaga guru yang sangat terbatas. Upaya yang dilakukan oleh zending untuk mengatasi kesulitan tersebut adalah dengan memasang iklan (pengumuman) tentang kebutuhan guru di Toraja yang disebarkan ke pulau Jawa dan tempattempat lain. Namun hal ini pun kurang mendapatkan respons. Kesulitan yang dihadapi oleh sekolah-sekolah yang didirikan di wilayah Rantepao semakin memuncak pada tahun 1917, yakni setelah pembunuhan A.A. van de Loosdrecht. Murid-murid sekolah semakin tidak berani ke sekolah. Guru-guru yang berasal dari Manado, Sangir, dan Ambon meminta kepada zending untuk berhenti. Kemudian pada tahun 1918 terjadi wabah Spanyol (ra'ba biang) yang menelan ribuan korban jiwa.

Berbagai kesulitan sebagaimana telah diuraikan di atas, menyebabkan beberapa sekolah untuk sementara di tutup bahkan tertutup sama sekali. Misalnya sekolah di Tondoklitak yang kemudian hari dipindahkan ke To'yasa, Sekolah di Pali-Bittuang yang baru dibuka kembali pada tahun 1920, sekolah di Baruppu' yang baru dibuka kembali 
pada tahun 1923, dan sekolah di Tonga yang baru dibuka kembali pada tahun 1938. Walaupun demikian, usaha-usaha GZB di Barana' yang dikerjakan oleh J. Belksma di kemudian hari membawa dampak besar bagi perkembangan PI dan pendidikan di Toraja. Sebab Noormaalcursus yang didirikan sebagai sekolah pendidikan guru menjadi pusat pembinaan calon-calon guru sekolah yang sekaligus calon-calon guru jemaat.

Yang tercatat sebagai murid dari tahun 1917-1918 Noormaalcursus Barana', yaitu: Alberth Dendang, T. Manoppo, H. Bela, L.Toban, F. Tangyong, F. Soloran, F. Dadi, W. Ali, J. Tambing, P. Nari, dan 3 orang dari Manado. ${ }^{21}$ Dalam perjalananya Noormaalcursus Barana' ini mengalami buka-tutup. Pada tahun 1918-1920 ditutup, kemudian dibuka kembali pada tahun 1920-1924. Namun pada tahun 1924-1927 ditutup lagi.

Pada tahun 1918 Noormaalcursus Barana' sudah menghasilkan angkatan guru yang pertama lalu ditutup. Kursus seharusnya berjalan 2 tahun, tetapi tuntutan kebutuhan akan tenaga guru sangat mendesak sehingga ujian penamatan sering dipercepat. ${ }^{22}$ Bahkan pernah proses belajar hanya berlangsung selama enam bulan saja, kemudian murid diikutkan ujian. Namun setelah kebutuhan akan tenaga guru sudah normal; proses belajar justru menjadi 3 tahun. Sebab 1 tahun dikhususkan untuk mendapatkan pengetahuan isi Alkitab.

Kendatipun mengalami buka-tutup, Noormaalcursus Barana' sangat membantu dalam memenuhi kebutuhan akan tenaga guru dan pengembangan pendidikan sekolah serta PI di Toraja. Setelah menjadi guru beberapa alumni Noormaalcursus Barana' mendirikan atau mencabangkan sekolah yang sudah ada. Di antaranya B. Rapa' yang setelah menjadi guru di beberapa tempat membuka sekolah di Nonongan pada tahun 1924 dan pada tahun 1929 membuka lagi sekolah di La'bo'. ${ }^{23}$ Beliau meninggal dunia pada tanggal 11 September 1939. Hal yang sama pun dilakukan oleh beberapa guru lainnya, seperti H. Bela.

Sejarah juga mencatat bahwa beberapa alumni Noormaalcursus Barana' yang berpengalaman melayani diangkat menjadi guru Injil dan kemudian dari guru Injil diangkat menjadi pendeta. ${ }^{24}$

\footnotetext{
${ }^{21}$ Sarira, Sketsa Pendidikan Kristen Gereja Toraja, 14-15.

${ }^{22}$ Sarira, Sketsa Pendidikan Kristen Gereja Toraja, 14-15.

${ }^{23}$ Ibid.

${ }^{24}$ J. A. Sarira, Benih Yang Tumbuh, Jilid VI (Rantepao: Badan Pekerja Sinode Gereja Toraja, 1974), 26.
} 


\section{Pendidikan Sekolah Khusus Wanita}

GZB menyediakan dana khusus kepada zendeling-zendeling untuk melaksanakan pendidikan bagi wanita yang bekerja di rumah zendeling. ${ }^{25}$ Khusus untuk zendeling yang melayani di Toraja pendidikan yang dilaksanakan bagi wanita yang bekerja di rumah zendeling dikenal dengan istilah ma' muri'. Di rumah zendeling mereka diajar menjahit, memasak, memelihara kebersihan, kesehatan, dan keindahan/kecantikan, memelihara anak. Mereka juga mendapatkan pendidikan agama dan pengetahuan umum.

Konferensi pendeta-pendeta pada bulan Juli 1936 memutuskan agar dana GZB yang dialokasikan bagi pendidikan wanita digunakan untuk mendirikan Sekolah Rumah Tangga. Berdasarkan keputusan tersebut, dibentuklah panitia penyelenggara pendirian Sekolah Rumah Tangga dengan susunan panitia sebagai berikut: 1) Ketua Kehormatan : $\mathrm{Nj}$. A. Seinstra-Maas (Nj. Tuang Petoro' Makale-Rantepao), 2) Ketua: Nj. G. Tanis-van Es, 3) Sekretaris merangkap bendahara: Nj. N. HeusdensBastiaanse, 4) Pembantu Umum: Nj. L.v.d. Veen-Spieth. ${ }^{26}$ Panitia inilah yang menyusun rencana anggaran, rencana pelajaran, mencari guru, pembangunan gedung dan persiapan-persiapan lain.

Pada tanggal 3 Maret 1938 Sekolah Rumah Tangga atau Sekolah Kepandaian Poeteri (Huishoudschool) dibuka di Rantepao dengan jumlah murid 50 orang. ${ }^{27}$ Salah seorang gurunya didatangkan khusus dari Yogyakarta yaitu Nn. J. M. Eggink. Selama menempuh proses pendidikan, murid-murid diasramakan. Setahun sebelum berdiri gedung sekolahnya; tempat belajar berlangsung di rumah S. T. Lande' dan asramanya di rumah Laupa'. Teori yang didapatkan di sekolah dimatangkan dalam praktik di asrama. Termasuk pendidikan agama pun diintensifkan di asrama. Sampai pada tahun 1942 sekolah ini telah menamatkan \pm 170 calon-calon ibu rumah tangga baik dan cakap atau siap menjadi nyora.

Secara keseluruhan keadaan sekolah Kristen yang diawasi oleh zending di Toraja pada tahun 1938; yaitu pada perayaan 25 Tahun Injil Masuk Toraja yang dapat diartikan pula genapnya 25 tahun Pendidikan Kristen di Toraja, digambarkan dalam tabel di bawah ini: ${ }^{28}$

\footnotetext{
${ }^{25}$ J. A. Sarira, Sketsa Pendidikan Kristen Gereja Toraja (Toraja: Panitia Panca Dasa Warsa Pendidikan Kristen gereja Toraja, 1967), 19-20.

${ }^{26}$ Sarira, Sketsa Pendidikan Kristen Gereja Toraja, , 19-20.

${ }^{27}$ J. R. Pasolon, Sejarah Gereja Toraja 1913-2013 (Draft), (Rantepao: Tim Penyusun Sejarah Gereja Toraja Intitut Teologi Gereja Toraja, 2011), 15.

${ }^{28}$ Sarira, Sketsa Pendidikan Kristen Gereja Toraja, 23.
} 


\begin{tabular}{|c|l|c|c|c|}
\hline No & \multicolumn{1}{|c|}{ Jenis Sekolah } & $\begin{array}{l}\text { Jumlah } \\
\text { Sekolah }\end{array}$ & $\begin{array}{l}\text { Jumlah } \\
\text { Guru }\end{array}$ & $\begin{array}{l}\text { Jumlah } \\
\text { Murid }\end{array}$ \\
\hline 1 & Sekolah Rakyat & 73 & 160 & 7546 \\
\hline 2 & Schakeschool Makale & 1 & 5 & 175 \\
\hline 3 & Vervolgschool Makale & 1 & 6 & 227 \\
\hline 4 & Sekolah Guru Barana' & 1 & 1 & 20 \\
\hline 5 & Sekolah Rumah Tangga & 1 & 2 & 50 \\
\hline 6 & Sekolah Guru Injil Barana' & 1 & 2 & 7 \\
\hline 7 & C.T.S (Cristelejkc Toraja Scool) & 79 & 178 & 8069 \\
\hline \multicolumn{2}{|l|}{ Jumlah 7 } & & & \\
\hline
\end{tabular}

Sedangkan sekolah pemerintah yang lebih dahulu ada, tidak mengalami pertambahan jumlah.

Dari 178 guru tersebut di atas, 174 adalah warga pribumi Indonesia yang berasal dari berbagai daerah, seperti Ambon, Manado, Minahasa, Sangir, Jawa, dan Toraja; dan 4 orang berkebangsaan Belanda. Dalam sejarahnya, jumlah sekolah terus bertambah.

\section{Masa Pendudukan Jepang (1942-1947)}

Pada tanggal 10 Februari 1942 Jepang menduduki Makassar dan kemudian Toraja. Pendudukan Jepang sangat berpengaruh terhadap kemerosotan perkembangan sekolah Kristen di Toraja. Pada masa awal pendudukan tentara Jepang, sekolah-sekolah zending yang ada masih dibiarkan beroperasi. Bahkan pemerintah Jepang mengangkat dan menggaji secara khusus pengawas yang bertugas mengawasi sekolahsekolah zending, yaitu mengangkat Sumbung yang bertugas di wilayah makale dan Sesa Tandirerung yang bertugas di wilayah Rantepao. ${ }^{29}$

Tetapi mulai 1 April 1943 pemerintah Jepang mengeluarkan peraturan baru yang sangat "mengebiri" sekolah-sekolah zending. Betapa tidak "mengebiri", sekolah-sekolah kristen bentukan zending diambil alih oleh pemerintah Jepang. ${ }^{30}$ Sekolah yang tadinya memakai bahasa pengantar berbahasa Belanda digantikan dengan menggunakan bahasa Indonesia. Sekolah Rumah Tangga ditutup. Para guru dilarang mengajarkan pendidikan agama di sekolah dan dilarang memimpin kebaktian. Pada hal sebelumnya guru sangat memegang peranan penting dalam PI. Gedung sekolah tidak boleh dijadikan tempat kebaktian. Pada hal waktu itu gedung gereja masih tidak cukup dihitung jari.

\footnotetext{
${ }^{29}$ Sarira, Sketsa Pendidikan Kristen Gereja Toraja, 25.

${ }^{30}$ Sarira, Benih Yang Tumbuh, Jilid VI, 43.
} 
Sementara itu, para utusan zending sudah tidak ada lagi. Jadi praktis kepemimpinan gereja beralih dengan sendirinya kepada warga pribumi asli dengan berbagai kelemahan dan keterbatasannya. Tanggal 14 Maret 1945, Jepang menyerah tanpa syarat karena Hirosima dan nagasaki dihancurkan dengan bom atom. Pada Tanggal 17 Agustus 1945, Ir. Soekarno dan Drs. Moh. Hatta atas nama bangsa Indonesia memproklamirkan kemerdekaan Indonesia. Sekalipun kemerdekaan Indonesia telah diproklamasikan, namun dari tahun 1946-1950 kekuasaan tentara Nica masih berkuasa di Sulawesi. Dalam masa-masa tersebut, sejarah menorehkan bahwa terjadi peristiwa pemaksaan agama di Sulawesi.

\section{Masa Gereja Toraja (1947-2013)}

Berdasarkan data-data historis yang penulis dapatkan melalui dokumen-dokumen yang ada, maka ada tiga macam pendidikan Sekolah Kristen yang dilaksanakan dan terus dikembangkan oleh GT yang merupakan warisan zending sejak dari awal sejarahnya hingga masa kini, yaitu pendidikan sekolah anak usia dini (Play Group) sampai dengan sekolah menengah umum/kejuruan, pendidikan tinggi umum, dan pendidikan teologi. Namun karena luasnya lahan garapan Gereja Toraja di bidang pendidikan, maka penulis sudah membatasi pada bab I bahwa yang dikaji adalah jenis pendidikan umum/kejuruan mulai dari pendidikan sekolah anak usia dini (Play Group) sampai dengan sekolah menengah umum/kejuruan,

Setelah Jepang menyerah, maka sekolah-sekolah zending yang diambil alih oleh pemerintah Jepang diwariskan kepada pemerintah Republik Indonesia. Pemerintah NIT (Negara Indonesia Timur) menyebutnya sebagai sekolah ikatan pool. Sekolah-sekolah yang dibekukan mulai dibuka kembali, seperti sekolah Christelijke Toradja School (CTS). Sekalipun berada dalam asuhan pemerintah, sekolah ikatan pool masih bercorak Kristen sebab umumnya guru-gurunya merupakan guru dari zaman zending. Sekolah negeri yang baru dibuka pun masih bernuansa Kristen; seperti SMP Negeri Rantepao (sekarang SMP 1 Rantepao) yang dibuka pada tahun 1946.

Guru-guru dari sekolah rakyat bekerja sama dengan jemaat-jemaat setempat dalam mendirikan sekolah baru atau mencabangkan sekolah yang sudah ada. Pada awal pendirian sekolah baru atau yang dicabangkan belajar di ruang gereja setempat. Pada tahun 1947 berbagai jenis jenjang sekolah lanjutan mulai berkembang, seperti : Middelbareshool yang dibuka oleh van de Berg tahun 1949, Noormaalschool di Makale yang dibuka oleh J. Tanis pada tanggal 1 Agustus 1949, dan Ambachtschool (sekolah teknik) yang dibuka oleh Leemans pada bulan September 
1949. ${ }^{31}$ Pada waktu itu, sekolah Teknik, SKP, dan Noormaalschool mendapatkan subsidi dari pemerintah NIT.

Pada tahun 1951 beberapa sekolah Kristen dibuka oleh tokohtokoh Kristen (Jemaat), yaitu: SMP Kristen Makale, SMP Kristen Rantepao, dan SMP Kristen Rembon. Kemudian pada tahun 1952 berdiri SMP Kristen Palopo dan pada tahun 1954 Kristen Ulusalu dan Masamba. Singkat cerita, sekolah-sekolah kristen terus bertambah dan pengelolaannya kemudian diserahkan kepada Gereja Toraja yang sudah berdiri sebagai satu sinode gereja.

Berhubung pendirian sekolah Kristen terus bertambah, maka Komisi Usaha Gereja Toraja (KUGT) memandang perlu untuk membuat sebuah Yayasan yang secara khusus mengurus pendidikan Sekolah sebagai bagian dari kesaksian dan pelayanan GT. Pada tanggal 28 Mei 1954 membentuk Yayasan Perguruan Kristen Toraja (YPKT) dengan Nomor Akte Notaris di Makassar Brund Erenstz yang kemudian diperbaharui pada tanggal 7 Oktober 1963 No. 74 oleh wakil notaris di Makssar Raden Emiel Abdulkarnen SH. ${ }^{32}$ Sebenarnya sejak sidang Sinode Am I Gereja Toraja tahun 1947 sudah digumuli dan diusulkan pembentukan suatu badan/komisi untuk mengurus sekolah-sekolah ikatan pool warisan zending, tapi diputuskan untuk ditunda karena sekolah-sekolah eks zending belum dikembalikan. ${ }^{33}$

Pada era tahuan 60-an, jumlah sekolah terus bertambah; baik SD maupun Sekolah Lanjutan. Utamanya sekolah kejuruan makin bertambah karena cukup tinggi permintaan kebutuhan tenaga kerja dalam rangka membangun bangsa pada waktu itu. SGB Kristen di Makale disetujui oleh pemerintah untuk dialihkan ke SMEA Kristen Makale bersubsidi yang diperluas menjadi sepuluh tempat. SMEA Kristen Makale ini, didirikan pada tanggal l Oktober 1958. Kemudian Sekolah Kerajinan bersubsisi di Rantepao dialihkan menjadi Sekolah Teknik Pertama, Sekolah Teknik Menengah (STM) Kristen Rantepao (STM Tagari) didirikan oleh PERGUKI (Persatuan Guru Kristen Republik Indonesia) pada tanggal 1 Agustus 1964. Sampai sekarang sekolah ini masih beroperasi dengan nama STM Tagari. SKKA Kristen Rantepao dibuka pada tanggal l Oktotober 1965 dan College pendidikan Guru Kristen serta College pendidikan teknik dibuka pada tahun 1967. Awal tahun 1967 YPKT telah mengasuh 208 buah sekolah yang berada di 251 tempat (208 buah sekolah dengan 43 cabang) dengan jumlah guru/dosen 1.341 orang (1.283 guru dan 58 dosen) dan 36.756

\footnotetext{
${ }^{31}$ Sarira, Sketsa Pendidikan Kristen Gereja Toraja, 27.

${ }^{32}$ Sarira, Benih Yang Tumbuh, Jilid VI, 232.

${ }^{33}$ Dokumen, Notulen Keputusan Sidang Sinode Am I Gereja Toraja, tanggal 25-28 Maret 1947.
} 
murid/siswa/mahasiswa. ${ }^{34}$ Perkembangan pendidikan di luar Toraja, yaitu daerah Seko sejarahnya sangat dramatis. Pada masa DI/TII rakyat di sana mengungsi ke berbagai tempat. Tetapi masyarakat Kristen dalam pengungsiannya mengusahakan membuka sekolah-sekolah Kristen. Sampai pada tahun 1967 sudah terdapat 13 SD, l SMP Kristen, dan 1 SMEP, serta di Sulawesi Tengah terdapat sebuah SMP Kristen dan dua buah SD.

Pendidikan sekolah Kristen di daerah-daerah yang penduduknya mayoritas beragama Islam di mana jemaat-jemaat GT berada juga mendapat perhatian. Sekolah-sekolah di wilayah Bugis-Makassar baru didirikan setelah YPKT berdiri. Sekolah-sekolah yang dimaksudkan adalah 2 SD di Makassar, SMP Elim Makassar, SD di Watam Pone Kabupaten Bone, SD dan SM di Pare Pare. Sekolah-sekolah Kristen di wilayah Bugis-Makassar murid-muridnya sebagian adalah anak-anak dari umat muslim.

Dalam perjalanan berikutnya, yakni dari tahun 1968 sampai sekarang YPKT mengalami pasang surut dalam perjalanannya. Dalam laporan Sidang Sinode Am XII tahun 1970 YPKT menetapkan periode ini sebagai periode intensifikasi yang lebih ditekankan pada peningkatan mutu pendidikan. Dari hasil identifikasi pengurus YPKT, rendahnya kualitas pendidikan di sekolah Kristen asuhan YPKT antara lain disebabkan oleh faktor daya, faktor dana dan faktor sarana prasarana.

Langkah-langkah yang diambil oleh pengurus YPKT mencakup tiga bidang utama yakni: Pertama, pada bidang organisasi dilakukan pembenahan organisasi dengan menciptakan sistem kerja yang efektif dan efisien. Kedua, pada bidang pengajaran dan pendidikan dilaksanakan pemberian beasiswa untuk penyiapan tenaga edukatif, tugas belajar untuk guru-guru YPKT, pendirian Pusat Latihan Guru (PLG) pada tanggal 4 November 1968. Ketiga bidang manajerial dilakukan rasionalisasi. Rasionalisasi dilakukan terutama karena didorong oleh faktor dana di mana sekolah-sekolah yang dikelola cukup banyak sementara dana yang tersedia tidak mampu menutupi kebutuhan yang ada.

Gagasan resionalisasi sebenarnya sudah mulai digulirkan tahun 1969 dan mencapai puncaknya pada tahun 1976, hal itu terjadi setelah Gereja Toraja mengadakan suatu konsultasi Pelayanan yang berpendapat bahwa pelayanan Gereja kedepannya merupakan pelayanan eksemplarim yang tidak mengabaikan kualitas. Dengan rasionalisasi ini, sebagian sekolah diserahkan pengelolaannya kepada pemerintah. Pertimbangan yang dijadikan dasar penyerahan sebagian sekolah kepada pemerintah adalah: 1) Ratio sekolah: keberadaan negeri terdekat; 2)

${ }^{34}$ Sarira, Sketsa Pendidikan Kristen Gereja Toraja, 31-32. 
Jumlah penduduk di lingkungan tersebut; 3) Kesanggupan masyarakat setempat untuk mendukung penyediaan sarana prasarana; 4) Presentase drop out; 5) Jarak antar sekolah. Berdasarkan pertimbangan tersebut, maka kebijakan yang diambil pengurus YPKT dalam rasionalisasi, yaitu: 1) Menutup sekolah yang tidak memenuhi syarat (kurang murid, tidak ada gedung, partisipasi dan dukungan masyarakat kurang); 2) Menggabungkan beberapa sekolah atau kelas jauh menjadi satu sekolah, atau satu kelas saja; 3) Membuka sekolah yang dibutuhkan seperti sekolah lanjutan, baik umum maupun kejuruan.

Akibat dari kebijakan rasionalisasi adalah sebanyak 107 SD YPKT bersama dengan 8 sekolah Katolik di Tana Toraja diserahkan pengelolaannya kepada pemerintah pada tanggal 31 Agustus 1976. Sedangkan sekolah yang ditutup antara lain: SMP Kr. Tondoklitak, SMP Kr.USIRAP Pangala', SMP Kr. Rembon, SMP Kr. Bittuang, SMP Kr. Masamba, dan lain-lain.

Sampai tahun 1988, jumlah sekolah dan siswa pada sekolah yang diasuh YPKT termasuk Propeka dapat dilihat pada tabel berikut:

Tabel : Statistik Sekolah YPKT tahun 1988

\begin{tabular}{|c|c|c|c|c|c|}
\hline \multirow[b]{2}{*}{ No } & \multirow{2}{*}{$\begin{array}{l}\text { Jenjang/Jenis } \\
\text { Sekolah }\end{array}$} & \multicolumn{3}{|c|}{ Jumlah } & \multirow[b]{2}{*}{ Ket. } \\
\hline & & Sekolah & Siswa & Guru & \\
\hline 1 & TK & 14 & 134 & 7 & $\begin{array}{l}\text { Belum termasuk } \\
\text { siswa dan guru TK } \\
\text { Pare-pare }\end{array}$ \\
\hline 2 & SD & 10 & 1.864 & 93 & $\begin{array}{l}\text { Belum termasuk } \\
\text { siswa SD Elim }\end{array}$ \\
\hline 3 & SMP & 15 & 3.794 & 170 & \\
\hline 4 & SMA & 5 & 2.219 & 47 & \\
\hline 5 & STM & 1 & 875 & 40 & \\
\hline 6 & SMEA & 4 & 3.375 & 45 & \\
\hline 7 & SPG & 1 & 325 & 11 & \\
\hline Jum. & 7 & 50 & 12.586 & 413 & \\
\hline
\end{tabular}

Untuk meningkatkan peran dan layanan sekolah yang diasuh YPKT Gereja Toraja kepada masyarakat, maka pada tanggal 23-25 Juni 2003 bertempat di Hotel Tikala (sek.Pusbintra Gereja Toraja) dilaksanakan temu karya Pengurus YPKT Pusat dan YPKT Cabang yang difasilitasi oleh Bpk G.Riphagen dan Bpk Ir.J.L.Para’pak, M.Sc. Temu karya ini menetapkan rumusan visi, misi dan bidang garapan mulai tahun ajaran 2003/2004 sampai 2011/2012. 
Adapun visi yang dirumuskan, yaitu: "Menjadi lembaga penyelenggara pendidikan yang berlandaskan kasih, mandiri dan terkemuka di kawasan Timur Indonesia." Misinya, yaitu: 1) Menyelenggarakan pendidikan dan pembelajaran berdasarkan ajaran kristiani yang mengedepankan etos kerja, profesionalitas, integritas, dedikasi dan akuntabilitas; 2) Mendorong partisipasi jemaat-jemaat dan unsur masyarakat lainnya dalam mendukung penyelenggaraan pendidikan yang bermutu; 3) Menyediakan sumber daya manusia pengelola pendidikan yang handal; 4) Mengembangkan kemitraan yang sinergis dengan para pembina, pengelola dan pemerhati pendidikan dalam dan luar negeri; 5) Menyediakan sarana prasarana pembelajaran yang memadai dalam jumlah dan kualitas. Ada pun bidang garapan utamanya, yaitu: 1) Pengembangan Kelembagaan dan Manajemen; 2) Kepegawaian dan Pengembangan Sumber Daya Manusia; 3) Pengembangan kurikulum dan pembelajaran; 4) Pengembangan SaranaPrasarana dan Pengelolaan Asset; 5) Pengembangan manajemen keuangan.

Dengan visi dan misi tersebut diatas, pengurus YPKT periode 2006-2011 menyusun renstra dan program kerja dalam prinsip "percepatan, peningkatan dan pengembangan." Dengan tujuan menjadikan sekolah kristen sebagai: "Christian character buildings community" sehingga sasarannya ialah semua orang yang ada dalam lingkungan YPKT, baik pembina, pengawas, pengurus harian yayasan, kepala sekolah, guru, pegawai dan peserta didik, memiliki dan menyatakan karakter kristiani yang cerdas, berhikmat dan berbudi pekerti.

Upaya yang dilakukan untuk percepatan, peningkatan, dan pengembangan sekolah, antara lain:

1. Meningkatkan kerjasama dengan semua pihak yang terkait yakni:

a. Meningkatkan peran Gereja Toraja (BPMS, BPMK, Pelayanan Kelompok Kategorial dan Jemaat-Jemaat) untuk menyatakan dukungan nyata bagi pengembangan sekolah sekolah YPKT.

b. Tetap menjalin dan berkordinasi dengan pemerintah daerah khususnya dengan Dinas Pendidikan Kab./Kota dalam rangka percepatan, peningkatan dan pembangunan sekolah sekolah YPKT.

c. Meningkatkan kerjasama dengan Majelis Pendidikan Kristen (MPK) baik tingkat Kab./Propinsi dan terutama MPK Pusat, Jaringan Kerja Lembaga Pelayanan Kristen, Badan Musyawarah Perguruan Swasta (BPMS) baik Kab/Propinsi maupun Pusat, Dewan Pendidikan Propinsi Sulawesi Selatan dan Kab.Tana Toraja dan Toraja Utara, dan berbagai lembaga yang peduli pada pendidikan. 
d. Melakukan kerjasama dengan Lembaga Penjaminan Mutu Pendidikan (LPMP) Sulawesi Selatan untuk meningkatkan mutu pendidikan dan tenaga kependidikan, Pusat Pendidikan dan Pengembangan Pendidik dan Tenaga Kependidikan (P4TK) Bandung untuk berbagai diklat Kepala Sekolah, guru dan tenaga kependidikan, Yayasan Pendidikan Pelita Harapan (YPPH) untuk penempatan guru-guru SMP/SMA dan SMK tamatan Universitas Pelita Harapan maupun untuk alih kelola manajemen SMP Kristen Rantepao, Assosiasi Yayasan untuk Bangsa (AYUB) untuk penerapan pendidikan berbasis enterpreneurship, ILO dan EMS untuk pelatihan keterampilan dasar komputer dan sepeda motor bagi anak putus sekolah, American Indonesia Exchange Foundation (AMINEF) untuk pengadaan guru asing di SMA Kr. Barana, dll.

e. Melanjutkan dan meningkatkan kerjasama dengan Stichting Bondgenoot Partner dari Belanda untuk pembanguna dan pengadaan sarana prasarana (bangunan dan peralatan pembelajaran)

2. Tetap mengupayakan percepatan untuk peningkatan kualitas pendidikan di sekolah YPKT, yang kemudian oleh pemerintah sejak April 2006 SMA Kristen Barana' ditetapkan sebagai sekolah Rintisan Bertaraf Internasional, menyusul SMK Tagari sebagai RSBI tahun 2008. Sementara itu sekolah-sekolah lain selalu dimotivasi untuk tetap memberi nilai tambah (karakter Kristiani) dan tetap diminati anak didik pada semua tingkatan.

3. Membuka Unit Sekolah Baru (USB) yakni SMK Pendolo dan SMK Seriti yang dibina oleh SMK Kristen Tagari, serta SMK Kristen Bittuang dibawah binaan SMK Kristen Makale, SMA Miallo Simbuang dibawah binaan SMA Kristen Makale. Selain itu membuka lima sekolah dasar di Simbuang (SD Tanete, SD Sarambu, Sarangdena', Miallo, Tarundung).

4. Bekerja sama dengan jemaat-jemaat untuk membuka Pendidikan Anak Usia Dini (PAUD) sebagaimana yang diamanatkan sidang Sinode Am XXII di Jakarta. PAUD memiliki posisi yang strategis dalam menghasilkan pendidikan yang berkualitas dan untuk penanaman serta pembentukan karakter kristiani pada diri anak sejak dini.

Sampai pertengahan tahun 2011 jumlah sekolah, guru, pegawai dan siswa pada sekolah sekolah asuhan YPKT GT tergambar dalam tabel di bawah ini. 
Tabel : Statistik Sekolah YPKT GT Tahun 2011

\begin{tabular}{|c|c|c|c|c|c|c|}
\hline \multirow[t]{2}{*}{ No } & \multirow{2}{*}{$\begin{array}{l}\text { Jenjang } \\
\text { Sekolah }\end{array}$} & \multicolumn{4}{|l|}{ Jumlah } & \multirow[t]{2}{*}{ Ket } \\
\hline & & Sekolah & Guru & Pegawai & Siswa & \\
\hline 1 & PG/TK & 56 & 161 & 2 & 1.514 & \\
\hline 2 & SD & 15 & 170 & 18 & 3.348 & \\
\hline 3 & SMP & 15 & 266 & 53 & 3.295 & \\
\hline 4 & SMA & 5 & 124 & 31 & 1.758 & \\
\hline 5 & SMK & 8 & 232 & 65 & 2.283 & \\
\hline Jlh. & 5 & 99 & 953 & 169 & 12.198 & \\
\hline
\end{tabular}

\section{Analisis Historis Kritis}

Dari uraian tentang sejarah singkat peran GT melaksanakan pendidikan Sekolah Kristen sebagaimana telah digambarkan mulai dari zaman zending sampai sekarang, nampak jelas bahwa sekolah-sekolah Kristen milik Gereja Toraja yang bermula dari sekolah zending telah memainkan peran yang cukup signifikan bagi pertumbuhan dan perkembangan masyarakat dan gereja. Sekolah telah menjadi salah satu alat pelayanan Gereja Toraja yang sangat efektif untuk mewujudkan panggilannya bagi masyarakat, bangsa dan negara. Sekolah milik gereja Toraja yang diasuh YPKT-GT telah menjadi berkat bagi banyak orang.

\section{Masa Zending}

Sejarah telah berbicara bahwa pemerintah kolonial dan teristimewa zending membuka babak baru bagi kemajuan masyarakat Toraja. Melalui pendidikan sekolah yang dikembangkan oleh utusan Indiche Kerk dan terutama zending GZB mengantar orang Toraja keluar dari kekurangtahuan menuju pada kecerdasan hidup. Betapa tidak Toraja harus bersyukur atas kemajuan karena pendidikan sekolah, sebab pada masa itu Toraja tidak hanya terpencil; tapi juga sangat terbelakang. Bahkan dapat dikatakan masyarakatnya masih primitif. Sebab dalam buku-buku etnologi waktu itu sebagaimana dikutip oleh J. A Sarira; suku Toraja digambarkan sebagai suku yang tidak memelihara kesehatan, memiliki adat memotong kepala, membunuh tukang sihir, perbudakan dan sebagainya. ${ }^{35}$

Lebih lanjut alasan penerapan privilege feodal di sekolah Landschapschool bahwa melalui pendidikan sekolah, pemerintah kolonial bermaksud melibatkan lapisan atas masyarakat Toraja dalam birokrasi kolonial. Sekolah digunakan sebagai sarana untuk merekrut tenaga administrasi kolonial yang nantinya akan berperan sebagai alat

${ }^{35}$ Sarira, Seri Benih Yang Tumbuh, Jilid VI, Suatu Studi Mengenai Gereja Toraja (Jakarta: LPS-DGI, 1975), 20. 
pemerintah kolonial dalam memudahkan upaya kolonialisme di Toraja. Jadi terjadi perpaduan kolonialisme dan feodalisme birokratik.

Previlage vested yang dilakukan oleh pemerintah kolonial dinetralisir oleh usaha zending dengan membuka volkschool yang terbuka bagi rakyat jelata sehingga pendidikan makin meluas di semua lapisan masyarakat. Walaupun sekolah-sekolah zending umumnya masih di dominasi oleh keturunan bangsawan. Dominasi kaum bangsawan pada sekolah-sekolah zending tentunya dipengaruhi sistem sosial kemasyarakatan Toraja yang mengenal sistim kasta.

Hal yang menarik bahwa kendati sekolah pemerintah kolonial berstatus "netral," artinya tidak memihak salah satu agama; gurugurunya tetap mengajarkan agama Kristen. Dua puluh murid yang dibaptis pada tanggal 16 Maret 1913 merupakan hasil dari pengajaran agama Kristen oleh guru dari luar Toraja di sekolah Landschapschool di Makale. Hal menarik berikutnya adalah Gereja Protestan (Protestantse Kerk in Nederlans-Indie) yang juga dikenal dengan nama Indiche Kerk yang dengan leluasa melakukan evangelisasi dan membuka sekolah. Pada hal sebagai lembaga negara ("geraja negara") sejatinya tidak mengadakan evangelisasi dan secara resmi kehadirannya hanya untuk memelihara kehidupan rohani anggota-anggota jemaatnya, yaitu guru, tentara dan pegawai pemerintah kolonial. Berdasarkan uraian-uraian di atas, maka dapat disimpulkan bahwa motivasi kegiatan kristenisasi dari Indiche Kerk di Makale yang didukung pemerintah kolonial dengan membuka sekolah di mana-mana dan membaptis anak-anak adalah lebih bersifat politik. Hal ini dapat dijelaskan dari metode yang dilakukan dengan membaptis sebanyak mungkin orang di wilayah yang diduduki dalam waktu yang secepat mungkin. Dapatlah dipahami, jika pada tahun 1915 sekolah-sekolah yang dibuka Indiche Kerk diserahkan pengelolaannya kepada zending GZB.

Usaha pemerintah kolonial dan Indiche Kerk membuka sebanyak mungkin sekolah di Toraja untuk memengaruhi kelas atas masyarakat Toraja, dinilai oleh masyarakat Toraja waktu itu; sebagai upaya mengangkut putra-putri terbaik Toraja untuk mengabdi kepada pemerintah kolonial. ${ }^{36}$ Akibatnya konsepsi demikian berpengaruh besar terhadap usaha zending GZB membuka sekolah-sekolah pada tahuntahun berikutnya.

Bidang pelayanan yang paling banyak dan serius ditangani oleh zending GZB dalam rangka PI adalah pendidikan di samping bidang yang lain, seperti pelayanan kesehatan. Tak bisa dipungkiri bahwa sejak awal kedatangannya zending GZB berbuat apa saja sesuai

\footnotetext{
${ }^{36}$ Sarira, Seri Benih Yang Tumbuh, Jilid VI, 128.
} 
kemampuannya bagi kemajuan orang Toraja melalui pendidikan sekolah. Hal itu nampak jelas dari pekerjaan van de Loosdrecht yang hanya dalam kurun waktu 7 bulan sejak kedatangannya telah berhasil membuka 11 sekolah. ${ }^{37}$ Sungguh merupakan hasil kerja yang sangat fenomenal dan spektakuler, jika memperhatikan situasi dan kondisi masyarakat Toraja pada waktu itu.

Strategi A. A. van de Loosdrech yang terlebih dahulu belajar bahasa daerah Toraja pada Dr. Adriani di Poso, mendekati para pemimpin lokal tradisional, dan membuka sekolah merupakan strategi PI yang tepat untuk masyarakat aggraris pegunungan seperti Toraja. Sebab umumnya masyarakat demikian, selain primitif; juga cukup kuat dengan tradisionalisme keagamaan (agama suku) sehingga sangat sulit untuk menerima hal yang baru dikenalnya, terutama dalam mengubah keyakinannya. Dalam kondisi yang demikian, maka mempelajari bahasa daerah dan mendirikan sekolah sebagai pos-pos PI di desa-desa di Toraja memiliki peranan yang sangat besar dalam menjangkau jiwa bagi Kristus.

Sekolah-sekolah yang didirikan zending GZB dalam rangka misi PI sangat tepat menjangkau generasi muda Toraja. Sebab umumnya orang tua yang sudah cukup kuat mengakar dalam keyakinan tradisional, yaitu alukta sebagai agama asli manusia Toraja sangat sulit untuk mengubah keyakinannya. Realita bersaksi bahwa "buah-buah bungaran" dalam gereja yang di kemudian hari menjadi Gereja Toraja adalah murid-murid pelajar di sekolah milik pemerintah kolonial Belanda di Makale. Walaupun tujuan utama pemerintah kolonial mendirikan sekolah tersebut bukan untuk evangelisasi, tetapi sekolah tersebut telah dipakai oleh Tuhan untuk menyelamatkan umatNya melalui guru-guru asal luar Toraja yang memperkenalkan Kristus bagi dua puluh murid sekolah Lanschap Makale yang dibaptis tanggal 16 Maret 1913. Walaupun sebenarnya tidak terbebas dari latar belakang yang negatif.

Kehadiran guru sekolah dianggap oleh masyarakat desa sebagai orang yang serba bisa dan patut di teladani. ${ }^{38}$ Selain sebagai pendidik bagi muridnya, guru juga menjadi pendidik bagi masyarakat sekitarnya. Guru pada masa itu membawa daya tarik bagi masyarakat dalam bidang kesehatan masyarakat dan ekonomi. Bahkan tidak jarang guru menjadi penasihat pemerintah setempat. Dapat dipahami jika dimasa-masa awal perkembangan Toraja cukup banyak orang Toraja yang berprofesi sebagai guru. Rata-rata generasi Toraja yang sukses adalah dari keturunan guru sekolah, guru Injil dan pendeta.

\footnotetext{
${ }^{37}$ Sarira, Seri Benih Yang Tumbuh, Jilid VI, 142.

${ }^{38}$ Sarira, Sketsa Pendidikan Kristen Gereja Toraja, 38.
} 
Sekolah sebagai pusat kegiatan kader yakni sebagai tempat pembentukan kader-kader pemimpin dalam gereja dan masyarakat. Noormaalcursus dan Sekolah Guru Injil yang didirikan oleh J. Belksma di Barana' serta Schakelschool Christelijke Toradja School sangat besar kontribusinya bagi kemajuan Toraja pada umumnya dan usaha PI pada khususnya.

Sampai tahun 1942 Noormaalcursus merupakan satu-satunya lembaga pendidikan yang menghasilkan tenaga pemimpin dalam gereja dan masyarakat. Pola pendidikan yang diterapkan di Noormaalcursus dengan menambah waktu studi 1 tahun yang dikhususkan untuk belajar agama cukup signifikan bagi pekerjaan PI setelah para murid terjun ke medan kerja sebagai guru. Sejarah mencatat bahwa alumnus-alumnus dari sekolah di Barana' tersebut, sangat militan dalam pekerjaan sebagai guru jemaat dan evangelis di samping sebagai guru di sekolah. Itu artinya pendidikan agama yang didapatkan di sekolah telah membentuk spiritualitas yang holistik dalam kehidupan pribadi murid yang memang telah disengajakan dari awal perencanaan sekolah melalui kurikulum.

Pola pendidikan sekolah zending tersebut di atas, tentunya dapat menjadi pembelajaran berharga bagi sekolah-sekolah umum Kristen dalam rangka memelihara identitas dan ciri khas. Sebab secara umum, sekolah-sekolah umum Kristen; khususnya yang di kelola Gereja Toraja sekarang ini hampir kehilangan ciri khasnya. Identitas sebagai sekolah Kristen kurang termaknakan dalam kehidupan sekolah. Sebagai contoh, pembinaan spiritualitas dan pengajaran PAK tidak ada perbedaan yang cukup mencolok bila dibandingkan dengan sekolah negeri. ${ }^{39}$

Putra-putri Toraja alumnus Lanschapschool dan schakelschool dapat melanjutkan pendidikan di luar Toraja, seperti "OSVIA (Lembaga Pendidikan Pegawai Pemerintah Kolonial) di Makassar, SPG berbahasa belanda di Solo, Sekolah Pertanian di Bogor, Sekolah Ekonomi Rumah Tangga Kristen di Yogyakarta dan lain-lain". ${ }^{40}$ Dengan demikian sudah ada pemuda Toraja yang melanjutkan studi ke Makassar dan Jawa. Di sana mereka mendengar tentang pergerakan kemerdekaan nasional yang dimotori pemuda-pemuda pelajar, seperti gerakan Budi Utomo, Sarekat Islam, Mohammadyah, Sumpah Pemuda, Jong Java, Jong Celebes, Jong Batak, Jong sumatera, dan sebagainya; serta dapat berhubungan dengan pemimpin-pemimpin nasional. Misalnya, J. Rapi' pernah menghadiri ceramah Mr. Soenarjo di Makassar tentang sumpah pemuda, kemudian

\footnotetext{
${ }^{39}$ Yan Malino, "Pendidikan Agama Kristen Skolah-Sekolah yang Dikelola Yayasan Perguruan Kristen Toraja-Gereja Toraja (YPKT-GT) dalam Usaha Menjawab Tantangan dan Peluang," Skripsi (STT Jaffray Makassar, 2003), 47-49.

${ }^{40}$ Terance W. Bigalke, Tana Toraja: A Social History of an Indonesian People (Leiden: KITLV Press, 2005), 157.
} 
curriculum dari A. Taula'bi' menyatakan bahwa dia berhubungan dengan taman siswa sewaktu berada di Yogyakarta (1933-1936), dengan Indonesia Muda, dengan pemimpin-pemimpin politik, dan pernah membantu redaksi "semangat Baru" (Majalah Perjuangan Kristen), aktif di Partai Kebangsaan Kristen (PKC) dan Persatuan Pergerakan Pemuda kristen (PPPK). ${ }^{41}$

Pemuda-pemuda Toraja yang kembali dari luar Toraja pada era tahun 1930-an telah dipengaruhi oleh ide nasionalisme. Walaupun ide nasionalisme yang ada pada saat itu masih bersifat kedaerahan yang ingin mendorong pendidikan dan kemajuan bagi kelompok etnis masingmasing. Pemuda-pemuda Toraja sudah sangat kritis sehingga tidak tanggung-tanggung mengkritisi pemerintah maupun zending. Dalam wawancara Th. Kobong dengan J. Rapi' pada bulan September 1985 menyatakan bahwa dia dibayang-bayangi oleh pihak polisi karena mengirim kue sebagai tanda simpati kepada empat pemuda Toraja yang ditahan karena pemberontakan di atas kapal "Zeven Provincien." ${ }^{4}$

Jauh sebelum PTC terbentuk, pada tahun 1926 telah terbentuk organisasi modern pertama di Toraja, yaitu "Bunga' Lalan" (perintis/pelopor) yang kemudian menjadi Perserikatan Bunga' Lalan (PBL) yang diketuai K. Kadang dan M. Biu' sebagai sekertaris. ${ }^{43}$ Selain PTC dan PBL, ada juga Persatuan Pemuda Toraja Christen (PPTC), Tengko Situru'na Lepongan Bulan dari wilayah Kesu', dan lain sebagainya sebagai organisasi pergerakan kemandirian etnis Toraja yang muncul mendorong Toraja ke arah yang lebih maju. Ide-ide pemudapemuda Toraja seperti F. Tangyong, A.T Taula'bi', F. Raru', J Tandikarrang, C. Parinding, J. Roma' dan lain-lain untuk kemajuan masyarakat nampak melalui tulisan-tulisan mereka dalam majalah Soelo (Obor) yang menyerukan agar orang Toraja bersatu dan mengejar "kemajuan".

Kekritisan orang muda Toraja yang telah menyelesaikan pendidikan di luar Toraja (Pulau Jawa) dinilai kurang sopan oleh zending dan dianggap tidak mau lagi mengakui otoritas zendeling. Lain halnya dengan $\mathrm{H}$. Kraemer dalam laporannya tentang medan kerja GZB, justru menasihatkan kepada zending agar tidak menganggap remeh peranan kaum cendikiawan muda Toraja (A. T. Taula'bi' dan C.

\footnotetext{
${ }^{41}$ Theodorus Kobong, Injil dan Tongkonan: Inkarnasi, Kontekstualisasi, Transformasi (Jakarta: BPK Gunung Mulia, 2008), 160.

${ }^{42}$ Ibid.

${ }^{43}$ Terance W. Bigalke, Tana Toraja; a Social History of an Indonesian People (Edisi Lama), (Leiden: KITLV Press, 2005), 155, 166, 174).

${ }^{44}$ Theodorus Kobong, Injil dan Tongkonan: Inkarnasi, Kontekstualisasi, Transformasi (Jakarta: BPK Gunung Mulia, 2008), 162.
} 
Parinding) melainkan melibatkan mereka dengan memberi tanggung jawab. ${ }^{45}$

Penilaian kurang sopan atas kekritisan intelektual-intelektual muda Toraja dan dilarangnya mereka oleh zending untuk mencampuri urusan politik waktu itu, sebernarnya merupakan konsekuensi dari hubungan antara zending dengan pemerintah kolonial. Sebab Pemerintah kolonial secara tidak langsung mendukung kegiatan PI yang dilakukan lembaga pekabaran Injil dengan memberikan subsidi di bidang pendidikan dan kesehatan. Dalam pekerjaannya para zendeling sering memintah bantuan kepada Gezaghebber bahkan tidak segansegan melaporkan warga pribumi yang dianggap tidak mematuhi keinginannya. ${ }^{46}$

\section{Masa Pendudukan Jepang}

Masa pendudukan Jepang mengakhiri dominasi pendidikan sekolah zending di Toraja. Masa pendudukan Jepang membawa perubahan yang besar bagi perkembangan pendidikan sekolah Kristen di Indonesia pada umumnya dan Toraja pada khususnya. ${ }^{47}$ Positifnya, pemerintah Jepang menghapus perbedaan kelas menurut ras dan kebudayaan dalam pendidikan sekolah. Tidak ada lagi perbedaan atau perlakuan khusus di sekolah, sekolah berbahasa belanda digantikan dengan bahasa Melayu. Tapi negatifnya ialah keluarnya putusan pemerintah Jepang tanggal 1 April 1943 untuk mengambil alih sekolahsekolah Kristen. ${ }^{48}$

Menurut J Rapi', pergerakan nasional kedaerahan oleh tokohtokoh intelektual mudah kristen Toraja hampir tak terdengar karena takut terhadap tindakan intimidasi Jepang yang main pukul dan siksa. ${ }^{49}$ Pertambahan umat Kristen semakin meningkat dari \pm 15.000 menjadi \pm $25.000{ }^{50}$ Walaupun hanya dipimpin oleh putra-putra daerah yang masih kurang berpengalaman dan kurang berpendidikan, tapi mereka adalah pekerja-pekerja yang setia dan berdedikasi tinggi. Hal itu membuktikan

${ }^{45}$ H. Kraemer, dalam Th. Van den End: Sumber-Sumber Zending Tentang Gereja Toraja 1901-1961, dokumen 134 (156), (Jakarta: BPK Gunung Mulia, 1994), 152-153.

${ }^{46}$ E. A. J. Nobele, dalam Th. Van den End: Sumber-Sumber Zending Tentang Gereja Toraja 1901-1961, dokumen 33 (47), (Jakarta: BPK Gunung Mulia, 1994), 124-127.

${ }^{47}$ Th. Van den End, Ragi Carita 2: sejarah Gereja di Indonesia 1860-an- sakarang, (Jakarta: BPK Gunung Mulia, 1989), 378.

${ }^{48}$ Notulen Koempoelan Pendeta-Pendeta, dalam Th. Van den End: SumberSumber Zending Tentang Gereja Toraja 1901-1961, dokumen 153 (176) , (Jakarta: BPK Gunung Mulia, 1994), 514-519.

${ }^{49}$ Theodorus Kobong, Injil dan Tongkonan: Inkarnasi, Kontekstualisasi, Transformasi (Jakarta: BPK Gunung Mulia, 2008), 176-177.

${ }^{50}$ Ibid., 178. 
bahwa ada tak satu pun di dunia yang dapat menghalangi Injil Kristus diberitakan. Semakin dibabat, maka akan semakin merambat.

\section{Masa Gereja Toraja}

Pendidikan sekolah Kristen Toraja memasuki babak baru setelah Jepang menyerah pada tahun 1945. Menyerahnya Jepang diikuti dengan penyerahan pengelolaan sekolah-sekolah Kristen warisan zending kepada pemerintah NIT yang dikenal dengan sekolah-sekolah ikatan pool. Alasan mengapa Jepang tidak mengembalikannya kepada gereja tetapi justru menyerahkan kepada pemerintah NIT kurang diketahui dengan pasti. Namun demikian dapat dianalisa dari kepergian zending dan belum terbentuknya organisasi induk gereja hasil PI zending di Toraja. Artinya zending tidak mempersiapkan pribumi sebagai ahli warisnya secara dejure.

Terbentuknya YPKT, kemudian YPTh, dan YPTKM merupakan wujud konsistensi Gereja Toraja bagi pembangunan nasional dalam mencerdaskan anak bangsa. Berdirinya YPKT pada tahun 1954 selain bertujuan untuk menangani sekolah-sekolah bentukan Gereja Toraja sekaligus dimaksudkan untuk mengurus pengembalian sekolah-sekolah eks zending yang masih dikelola pemerintah. Jadi faktor yang melatar belakangi pendirian YPKT, yaitu faktor ekstenal berupa peluang yang disediakan negara melalui perangkat perundang-undangan yang berlaku (aspek sosial politik) dan faktor internal berupa tanggung jawab panggilan gereja (aspek teologis eklesiologis). ${ }^{51}$

Dengan kembalinya sekolah eks zending menambah jumlah Sekolah yang ditangani YPKT-GT. Itu artinya beban tugas dan tanggung jawab YPKT yang secara khusus menangani pendidikan umum/kejuruan milik Gereja Toraja semakin bertambah pula. Berdasarkan laporannya YPKT pada Sidang Sinode AM XII Gereja Toraja tahun 1970, maka A.K. Sampe Asang membagi 3 fase perjalanan YPKT menangani sekolahsekolah yang dikelolanya, yaitu rehabilitasi, fase konsolidasi, dan fase intensifikasi. $^{52}$ Ketiga fase ini sekaligus menguak perkembangan, permasalahan dan tantangan pendidikan sekolah Kristen Gereja Toraja. Melalui fase-fase yang dimaksudkan dapat tergambar strategi YPKT dalam mengelola pendidikan sekolah Kristen YPKT.

\footnotetext{
${ }^{51}$ A.K. Sampe Asang, Skripsi: Partisipasi Gereja dalam Pendidikan; Suatu Studi tentang Peranan Yayasan Perguruan Kristen Toraja (YPKT) dalam Pendidikan Formal di Indonesia (STT Intim Ujung Pandang, 1988), 54-66.

${ }^{52}$ A.K. Sampe Asang, Skripsi: Partisipasi Gereja dalam Pendidikan; Suatu Studi tentang Peranan Yayasan Perguruan Kristen Toraja (YPKT) dalam Pendidikan Formal di Indonesia (STT Intim Ujung Pandang, 1988), 68-73.
} 
Periode (1954-1960) disebut fase rehabilitasi. Oleh karena, penanganan pendidikan sekolah Kristen difokuskan pada pembangunan fisik sekolah-sekolah dan persiapan pengembalian sekolah-sekolah eks zending serta pembukaan sekolah-sekolah baru berdasarkan tuntutan kebutuhan masyarakat. Dalam rangka memenuhi kebutuhan pembanguanan masyarakat, maka dalam periode ini dibuka sekolahsekolah kejuruan; seperti Sekolah Usaha Tani, Sekolah Teknik, Sekolah Guru, Sekolah Keputerian, dan Sekolah Ekonomi. ${ }^{53}$

Fase konsolidasi (1960-1964), oleh karena pada periode ini upaya pengembangan pendidikan sekolah Kristen oleh YPKT difokuskan pada upaya menciptakan efisiensi dan efektifitas kerja dari seluruh perangkat kerja yang ada. Upaya konsolidasi ditetapkan dalam konferensi tahun 1963 di Tondok Litak berupa inpassing guru-guru ke dalam YPKT dan gedung-gedung, serta mobilair oleh Persekutuan Orang tua Murid (POM) ${ }^{54}$ Strategi yang ditempuh adalah mengadakan rapat, konperensi studi, upgrading, kursus-kursus, dan lain-lain, yang dimaksudkan sebagai upaya konsolidasi internal. Selain konsolidasi internal, upaya perbaikan pengelolaan pendidikan sekolah Kristen oleh YPKT dilakukan juga konsolidasi eksternal dengan pemerintah dan orang tua murid.

Fase intensifikasi (1964-1980), oleh sebab usaha pengelolaan pendidikan sekolah Kristen lebih diarahkan pada peningkatan kualitas proses pendidikan yang telah dipersiapkan sejak tahun 1964 dengan menintensifkan perangkat kerja organisasi dan mengintensifkan peningkatan kualitas pengajaran. ${ }^{55}$ Faktor-faktor penyebab rendahnya kualitas pendidikan sekolah Kristen asuhan YPKT diklasifikasikan dalam tiga faktor, yaitu daya, dana, sarana dan prasarana. Hal ini bisa menunjukkan kelemahan pengelolaan sekolah-sekolah Kristen Gereja Toraja dalam hal administrasi personalia, administrasi keuangan dan administrasi sarana prasarana. Jika pada maza zending persoalan pembiayaan tidak terlalu menjadi masalah karena sumber pendanaan utama dari lembaga zending di samping dana dari masyarakat, maka pada masa Gereja Toraja sekolah-sekolah Kristen mengalami kesulitan dalam hal pembiayaan operasional sekolah. Masalah finansial senantiasa menjadi permasalahan yang hangat dibicarakan setiap kali sidang sinode gereja Toraja.

\footnotetext{
${ }^{53}$ J.A. Sarira, Sketsa Pendidikan Kristen Gereja Toraja (Toraja: Panitia Panca Dasa Warsa Pendidikan Kristen gereja Toraja, 1967), 43.

${ }^{54}$ Dokumen, Laporan YPKT pada Sidang Sinode AM XIII Gereja Toraja, tanggal 9-16 April 1972, Lampiran 1, halaman 3.

${ }^{55}$ Dokumen, Laporan YPKT pada Sidang Sinode AM XIII Gereja Toraja, tanggal 9-16 April 1972, Lampiran 1, halaman 2.
} 
Sebenarnya untuk menanggulangi masalah finasial, maka sejak sinode V dibentuk satu seksi khusus dalam struktur Gereja Toraja, yaitu seksi keuangan. Salah satu faktor kesulitan finansial yang dihadapi Gereja Toraja sejak awal sampai sekarang adalah kurangnya kesadaran dari anggota jemaat mengenai tanggung jawabnya untuk menunjang pendanaan pelayanan gereja. ${ }^{56}$ Strategi yang ditempuh dalam menangani ketiga faktor tersebut adalah menata ulang perangkat kerja, khususnya struktur kerja YPKT dan perbaikan kualitas pendidikan dan pengajaran. ${ }^{57}$

Upaya peningkatan kualitas pendidikan dan pengajaran dilakukan melalui program pemberian beasiswa, tugas belajar, pusat latihan guru, bintang pelajar dan program rasionalisasi. ${ }^{58}$ Sejak tahun 1964, YPKT memberikan beasiswa kepada 52 orang mahasiswa di berbagai Perguruan Tinggi dengan berbagai disiplin Ilmu dan sejak tahun 1967 secara berangsur-angsur kembali menjadi tenaga inti di sekolah-sekolah asuhan YPKT. Program pemberian tugas belajar mulai dilaksanakan sejak tahun 1966 dengan tujuan peningkatan pengetahuan guru pada disiplin ilmu masing-masing. Program bintang pelajar dilakukan sejak 1964 dengan tujuan merangsang peningkatan prestasi belajar murid/siswa sekolah melalui pemberian penghargaan.

Program rasionalisasi mulai dilaksanakan pada tahun 1969, yaitu meninjau kembali kebijakan pengelolaan pendidikan sekolah kristen asuhan YPKT. Langkah rasionalisasi yang dilakukan dengan cara menutup sekolah-sekolah yang tidak memenuhi syarat, menggabungkan beberapa sekolah/kelas, dan membuka sekolah-sekolah baru sesuai tuntutan kebutuhan masyarakat merupakan kebijakan yang tepat untuk peningkatan kualitas pengelolaan pendidikan sekolah kristen.

Tapi penyerahan sekolah-sekolah asuhan YPKT sebanyak 107 buah kepada pemerintah dapat dinilai sebagai kebijakan yang kurang tepat. Sebab dengan susah payah gereja mengembalikan 65 buah sekolah dari 103 buah sekolah ikatan pool warisan zending pada tahun 1959. Tapi dalam jangka waktu 17 tahun (1976) diserahkan 107 buah sekolah. Bagaimana pun sulitnya tantangan yang dihadapi oleh YPKT pada masa itu, namum peristiwa penyerahan 107 buah sekolah dapat dikatakan sebagai sebuah "kecelakaan" dalam sejarah pendidikan sekolah Kristen Gereja Toraja. Hal ini menandakan bahwa policy yang diterapkan dan strategi pengelolaan pendidikan sekolah Kristen Geraja Toraja dalam

\footnotetext{
${ }^{56}$ Dokumen. Notulen Sidang Sinode AM V Gereja Toraja 26Pebruari-5 Maret 1955.

${ }^{57}$ A.K. Sampe Asang, Skripsi: Partisipasi Gereja dalam Pendidikan; Suatu Studi tentang Peranan Yayasan Perguruan Kristen Toraja (YPKT) dalam Pendidikan Formal di Indonesia (STT Intim Ujung Pandang, 1988), 73-80.

${ }^{58}$ Ibid., 75-77.
} 
kurun waktu 17 tahun kurang jeli membaca tanda-tanda zaman. Bisa dikatakan bahwa pada masa itu, Gereja Toraja masih lemah dalam hal manajemen perencanaan persekolahan.

Tahun 1980-2000 merupakan fase normalisasi pendidikan sekolah kristen Gereja Toraja. Penulis menyebutnya sebagai fase normalisasi karena pada periode-periode sebelumnya penanganan pendidikan sekolah Kristen dikonsentrasikan pada kegiatan intensifikasi program khususnya melalui kebijakan rasionalisasi. Secara garis besar pengelolaan pendidikan sekolah Kristen Gereja Toraja dalam kurun waktu \pm 20 tahun diarahkan pada peningkatan ciri khas dan citra sekolah-sekolah Kristen, peningkatan mutu pelajaran, peningkatan sarana dan prasarana. ${ }^{59}$ Usaha terutama difokuskan pada mewujudnyatakan identitas dan ciri khas sebagai sekolah yang berdiri atas dasar iman kepada Kristus dengan memelihara citra pendidikan yang berkualitas. Dari sinode ke sinode, peningkatan ciri khas dan citra sekolah Kristen Gereja Toraja terus menjadi bahan pergumulan.

Tahun 2000-sekarang merupakan fase pengembangan pendidikan sekolah Kristen Gereja Toraja. Penulis menyebutnya sebagai fase pengembangan karena garis besar kebijakan yang tertuang dalam Rencana Strategis (Renstra) jangka panjang (lima tahun) dan Program Kerja Satu Tahunan (Prosata) dikonsentrasikan pada pengembangan kelembagaan dan manajemen, pengembangan sumber daya manusia, pengembangan kegiatan belajar mengajar, pengembangan sarana prasarana, dan pengembangan kemampuan pendanaan dan pengelolaan keuangan. ${ }^{60}$ Latar belakang policy pengembangan pendidikan sekolah Kristen adalah munculnya penilaian umum bahwa kualitas pendidikan sekolah Kristen dalam lingkup pelayanan YPKT mengalami penurunan. Hal ini juga dimaksudkan oleh YPKT untuk menyikapi arus perubahan oleh perkembangan IPTEK.

Mencermati renstra, program, dan kegiatan tersebut di atas, maka ada banyangan prospek pendidikan sekolah Kristen Gereja Toraja menghadapi abad 2l. Namun melihat realitas implementasi kurang memberi harapan. Sebab dalam pantauan penulis, antara gagasan dan implementasi masih sangat kurang. Contoh kecil saja penyusunan sejarah pendidikan Kristen di tanah Toraja yang sudah diprogramkan sejak tahun 2005 bertepatan dengan perayaan HUT 50 tahun YPKT dan tim penulis sudah terbentuk, tapi sampai pada perayaan 100 tahun Injil Masuk Toraja (IMT) di tahun 2013 ini belum terealisasi. Sungguh suatu

\footnotetext{
${ }^{59}$ Dokumen, Laporan Umum Badan Pekerja Sinode Gereja Toraja kepada Persidangan Sinode Am XIX, 29 Juli s/d 7 Agustus 1992, di Jemaat Rantepao - Tana Toraja.

${ }^{60}$ Dokumen Laporan Pengurus YPKT Periode 2001-2006), Dalam lampiran II (OIG \& Unit Kerja) Laporan Badan Pekerja Sinode Gereja Toraja, 108-115.
} 
hal yang sangat ironis, dalam jangka waktu \pm 7 tahun, tim penulis dan pengurus YPKT belum dapat mewujudkan kerinduan para pendahulu pelaku pendidikan sekolah Kristen Gereja Toraja.

Hal kedua yang patut dikritisi adalah penataan administrasi, khususnya dokumentasi arsip perjalanan perkembangan pendidikan sekolah kristen masih cukup memprihatinkan. Sebab dokumendokumen penting sehubungan dengan hal itu masih sangat terbatas. Kenyataan tersebut dirasakan langsung oleh penulis dalam penelitian. Jadi dapat diketahui kendala belum terealisasinya penulisan buku sejarah pendidikan sekolah Kristen di Tana Toraja yang sudah lama menjadi impian. Kiranya ke depan impian tersebut tidak tinggal sebatas angan-angan yang tak kesampaian. Untuk itu dibutuhkan sebuah komitmen dan tindakan serius yang nyata dari para pemerhati pendidikan sekolah Kristen Gereja Toraja.

\section{Refleksi Teologis}

"Sebab aku mempunyai kekuatan yang kokoh dalam Injil, karena Injil adalah kekuatan Allah yang menyelamatkan setiap orang yang percaya, ..." (Roma 1:16). Kebenaran dari Injil sebagai kekuatan Allah yang menyelamatkan nyata bagi Toraja. Tak bisa dipungkiri bahwa Injil telah menyelamatkan Toraja dan orang Toraja. Injil telah membawa perubahan-perubahan mendasar dan besar dalam berbagai bidang kehidupan yang telah dinikmati masyarakat dan orang Toraja. Salah satunya adalah di bidang pendidikan melalui pendidikan formal di Toraja.

Karena Injil, maka manusia Toraja dapat mengenal pendidikan formal melalui sekolah. Kekuatan Injil yang menyelamatkan orang yang percaya nyata melalui pendidikan sekolah Kristen yang membebaskan manusia Toraja dari kegelapan karena kekurangtahuannya. "Kamulah bangsa yang terpilih, imamat yang rajani, bangsa yang kudus, umat kepunyaan Allah sendiri, supaya kamu memberitakan perbuatanperbuatan yang besar dari Dia, yang telah memanggil kamu keluar dari kegelapan kepada terangNya yang ajaib" (1 Ptr. 2:9). Injil telah mencerdaskan manusia Toraja melalui pendidikan di sekolah, sehingga manusia Toraja terpulihkan harkat dan martabatnya sebagai gambar dan rupa Allah (Kej.1:26-27).

Kekuatan Injil melalui sekolah-sekolah Kristen dari zaman zending sampai masa Gereja Toraja nyata telah, sedang, dan akan terus menerus memanusiakan manusia Toraja. Sejarah membuktikan bahwa sekolahsekolah yang dikelola oleh gereja berawal dari masa zending sampai dengan masa Gereja Toraja telah mewujudkan restorasi di Toraja yang merupakan tugas panggilan gereja terhadap dunia. Sekolah-sekolah Kristen, para pelajar Kristen, dan guru-guru Kristen serta seluruh 
komponen pendidikan sekolah kristen telah membuktikan diri sebagai motivator-motivator dan pelaku bagi kemajuan Toraja. Kader-kader gereja dan masyarakat yang ditelorkan menjadi motivator dan fasilitator pembangunan bagi kemajuan gereja dan masyarakat Toraja pada khususnya, bangsa dan negara pada umumnya.

Menjadi tanggung jawab gereja; baik secara individual maupun persekutuan untuk mengatakan: "Semarak kemuliaan-Mu yang agung dan perbuatan-perbuatan-Mu yang ajaib akan kunyanyikan. Kekuatan perbuatan-perbuatan-Mu yang dahsyat akan diumumkan mereka, dan kebesaran-Mu hendak kuceritakan. Peringatan kepada besarnya kebajikan-Mu akan dimasyhurkan mereka, dan tentang keadilan-Mu mereka akan bersorak-sorai" (Maz. 145:5-7). Peringatan dan perayaan 100 Tahun Injil Masuk Toraja (IMT) yang berarti juga 100 tahun pendidikan sekolah Kristen hadir di Toraja menjadi momentum yang tepat untuk menyatakan komitmen iman untuk mengembangkan pendidikan sekolah Kristen menjadi lebih berkualitas dari yang sebelumnya.

Yesus Kristus itulah kepala gereja mengamanatkan: "Karena itu pergilah, jadikanlah semua bangsa murid-Ku dan baptislah mereka dalam nama Bapa dan Anak dan Roh Kudus, dan ajarlah mereka melakukan segala sesuatu yang telah Kuperintahkan kepadamu. Dan ketahuilah, Aku menyertai kamu senantiasa sampai kepada akhir zaman." (Mat.28:19-20). Bila gereja Toraja dan masyarakat Kristen Toraja sungguh pengikut Kristus yang setia, maka menjadi tugas dan tanggung jawabnya untuk memberitakan Injil dan Pengajaran. Salah satu konteks PI dan Pengajaran Kristen adalah pendidikan di Sekolah. Pendidikan sekolah Kristen Gereja Toraja telah berperan, sedang berperan dan akan terus berperan bagi pembebasan manusia secara holistik. Biarlah hanya Kristus terus dimuliakan melalui usaha pendidikan sekolah Kristen Gereja Toraja. Biarlah masing-masing orang yang terberkati karena Injil melalui pendidikan Sekolah berkata: "Ajarlah kami menghitung hari-hari kami sedemikian, hingga kami beroleh hati yang bijaksana" (Mazmur 90:12).

\section{PENUTUP}

\section{Kesimpulan}

Sejarah pendidikan sekolah Kristen Toraja seiring sejalan dan seusia dengan masuknya Injil di Toraja. Injil sebagai kekuatan Allah yang menyelamatkan dan keKristen dapat diterima baik oleh masyarakat Toraja oleh karena strategi PI yang diterapkan zending khususnya A.A. van de Loosdrec sangat relevan dan cukup kontekstual untuk 
masyarakat Toraja, yaitu dengan terlebih dulu mempelajari bahasa dan kebudayaan Toraja, pendekatan kepada tokoh masyarakat/pemimpin lokal masyarakat Toraja, dan membuka sekolah.

Pada zaman zending pendidikan sekolah Kristen menjadi pilar penopang pekabaran Injil, pertumbuhan dan perkembangan gereja Toraja pada khususnya dan kemajuan masyarakat Toraja pada umumnya. Kegiatan persekolahan sering menjadi sarana untuk mengumpulkan masyarakat datang mendengar firman Tuhan. Gedung sekolah menjadi tempat pembinaan keagamaan (tempat ibadah). Guru sekolah kebanyakan merangkap sebagai penginjil dan guru jemaat. Halhal inilah yang mempercepat perkembangan gereja di Toraja.

Faktor penunjang kualitas sekolah, guru sekolah dan guru Injil pada zaman sending didukung dengan sarana asrama. Kendala yang dihadapi, yaitu kesadaran masyarakat akan arti penting dari pendidikan sekolah formal. Hal itu didukung dengan konsepsi masyarakat bahwa zending dan pemerintah kolonial sama saja. Itu diakibatkan oleh adanya kolaborasi antara zending dengan pemerintah kolonial. Menjadi pelajaran yang berharga dalam usaha persekolahan ialah bila sulit untuk memilah antara kepentingan gereja dengan kepentingan pemerintah.

Pada masa Gereja Toraja (1947-sekarang) pendidikan sekolah Kristen umum dikembangkan dibawa pengelolaan Yayasan Perguruan Kristen Toraja (YPKT) yang menangani pendidikan sekolah umum/kejuruan dari Taman Bermain/TK sampai dengan SMA/SMK. Setelah Jepang menyerah dan Gereja Toraja berdiri sendiri sebagai sebuah institusi gereja lokal, maka sekolah-sekolah Kristen terus berkembang. Sekolah Kristen yang dikelola Gereja Toraja semakin bertambah setelah dikembalikannya sekolah-sekolah ikatan pool warisan zending kepada Gereja Toraja di bawa asuhan YPKT. Jumlah sekolah Kristen ikatan pool yang disetujui DPRS Tana Toraja untuk serahkan kembali kepada gereja Toraja sejumlah 103 buah sekolah, tapi hanya disetujui oleh pemerintah Sulawesi Selatan sebanyak 65 buah sekolah pada tahun 1959.

Mulai dari Gereja Toraja berdiri sampai di era reformasi, Identitas, ciri khas dan citra sekolah asuha YPKT sebagai sekolah Kristen tetap digumuli di sepanjang eksistensinya. Menurunnya citra sekolah Kristen asuhan YPKT sejak era tahun 90-an bahkan sampai era reformasi diakibatkan oleh di akibatkan oleh tiga faktor utama yaitu: daya, dana, dan sarana prasarana sekolah. Namun patut dicatat bahwa samapai era tahuan 2000-an ini, partisifasi bantuan finansial dan sarana prasarana dari masyarakat masih terbilang cukup minim. Bantuan dari pemerintah pun masih terhitung kurang. 


\section{KEPUSTAKAAN}

Alkitab

Lembaga Alkitab Indonesia. Alkitab. Jakarta: LAI, 1999

Buku-Buku

Ahmadi, Abu dan Uhbiyati,Nur. Ilmu Pendidikan. Jakarta: PT Rineka Cipta, 1991.

Bigalke, Terance W. Tana Toraja; A Social History of an Indonesian People. Leiden: Singapore University Press, 2005.

Kobong, Theodorus. Injil dan Tongkonan: Inkarnasi, Kontekstualisasi, Transformasi. Jakarta: BPK Gunung Mulia, 2008.

Nuhamara, Daniel. Materi Pokok Pembimbing Pendidikan Agama Kristen; Modul 1-9. Jakarta: Dirjen Bimas Kristen Protestan-Departemen Agama Republik Indonesia, 1995.

Panitia 100 Tahun Injil Masuk Toraja. Panduan Umum Ibadah Syukur dan Perayaan 100 Tahun Injil Masuk Toraja. Rantepao: Sekretariat Panitia, 2013.

Pasolon, J. R. Garis besar Sejarah Gereja Toraja (Bagian I, 1913-1967) dalam Sejarah Gereja Toraja 1913-2013 (Draff). Rantepao: Institut Gereja Toraja.

Sarira, J. A. Seri Benih Yang Tumbuh, Jilid VI, Suatu Studi Mengenai gereja Toraja. Jakarta: LPS-DGI, 1975.

Sarira, J. A. Sketsa Pendidikan Kristen Gereja Toraja. Toraja: Panitia Panca Dasa Warsa Pendidikan Kristen gereja Toraja, 1967.

Van den End, Th. Sumber-Sumber Zending Tentang Sejarah Gereja Toraja 1901 1961. Seri Sumber-Sumber Sejarah Gereja Di Indonesia. Jakarta: BPK Gunung Mulia, 1994.

Van den End, Th. Ragi Carita 2: sejarah Gereja di Indonesia 1860-ansekarang, (Jakarta: BPK Gunung Mulia, 1989.

Skripsi

Malino, Yan. Pendidikan Agama Kristen Skolah-Sekolah yang Dikelola Yayasan Perguruan Kristen Toraja-Gereja Toraja (YPKT-GT) dalam Usaha Menjawab Tantangan dan Peluang. Makassar: STT Jaffray Makassar, 2003. 
Asang, A.K. Sampe. Partisipasi Gereja dalam Pendidikan: Suatu Studi tentang Peranan Yayasan Perguruan Kristen Toraja (YPKT) dalam Pendidikan Formal di Indonesia. STT Intim Ujung Pandang, 1988.

\section{Dokumen}

Dokumen, Laporan Majelis Pertimbangan Gereja Toraja pada SSA XXIII Gereja Toraja di Tallung Lipu, 2-9 Juli 2012.

Laporan YPKT pada Sidang Sinode Am XIII Gereja Toraja, tanggal 9-16 April 1972.

Laporan Umum Badan Pekerja Sidang Sinode Am XIX Gereja Toraja , 29 Juli s/d 7 Agustus 1992, di Jemaat Rantepao - Tana Toraja.

Laporan Pengurus YPKT Periode 2001-2006), Dalam lampiran II (OIG \& Unit Kerja) Laporan Badan Pekerja Sinode Gereja Toraja Pada Sinode Am XXI.

Notulen. Sidang Sinode Am V Gereja Toraja, Tanggal 26 Pebruari-5 Maret 1955.

Notulen. Keputusan Sidang Sinode Am XI Gereja Toraja tahun 1967 di Sa'dan. Salinan Surat Keputusan Menteri Pendidikan Pengajaran dan Kebudayaan Republik Indonesia Nomor:22382/B , Jakarta: 12 Pebruari 1957. 